\title{
Combining phosphorus placement and water saving technologies enhances rice production in phosphorus-deficient lowlands.
}

\section{Authors:}

P. De Bauw ${ }^{1}$, E. Vandamme ${ }^{2}$, K. Senthilkumar ${ }^{3,4}$, A. Lupembe ${ }^{3}$, Erik Smolders' ${ }^{1}$, R. Merckx ${ }^{1}$

${ }^{1}$ Katholieke Universiteit Leuven, Dept. of Earth and Environmental Sciences, Belgium

${ }^{2}$ International Potato Center (CIP), P.O. Box 1269, Kigali, Rwanda

${ }^{3}$ Africa Rice Center (AfricaRice), P.O. Box 33581, Dar es Salaam, Tanzania

${ }^{4}$ Africa Rice Center (AfricaRice), P.O. Box 1690, Antananarivo, Madagascar

*Corresponding author: Pieterjan.debauw@kuleuven.be

\section{Abstract}

Lowland rice production in sub-Saharan Africa (SSA) is often limited by water supply and low phosphorus (P) availability and efforts are needed towards more efficient management of both resources. Field and pot experiments were set up to evaluate combinations of water saving technologies and P placement methods with due attention to treatment effects on root architecture. A two-year field experiment was set up in a lowland rice field in Tanzania with factorial combinations of different levels of water supply (field capacity, alternating wetting drying, permanent flooding) and P application (no P; 3.45 and $6.90 \mathrm{~kg}$ $\mathrm{ha}^{-1}$ placement versus $25 \mathrm{~kg} \mathrm{ha}^{-1}$ broadcast), thereby testing residual effects in year 2 . A trial in large pots was additionally performed with equivalent treatments and allowing measurements of soil solution composition, fertilizer efficiency, and root density versus depth. Rice grain yields ranged $0-5$ ton ha ${ }^{-1}$ and mainly responded to $P$ application. The $P$ placement at the lowest $P$ rate resulted in higher grain yield at field capacity $\left(2.0-2.5\right.$ ton ha $\left.{ }^{-1}\right)$ than in flooded rice $\left(1.2-1.6\right.$ ton ha $\left.{ }^{-1}\right)$, whereas these differences were absent at higher P rates. Lower water supply at field capacity enhanced root growth and rooting depth, decreased nodal root thickness and enhanced root $\mathrm{P}$ uptake efficiency compare to flooded condition. Modelling $\mathrm{P}$ diffusion outwards the granules showed more restricted $\mathrm{P}$ diffusion under reduced water supply and, therefore, less P immobilization in the soil under field capacity. These differences between water treatments were more pronounced at lower than at higher P supply. This study shows that root responses and $\mathrm{P}$ diffusion outwards granules explain how water and $\mathrm{P}$ resources can be saved with $\mathrm{P}$ placement in combination with water saving technologies. P placement forms a good option to intensify rice production while countering soil $\mathrm{P}$ decline in $\mathrm{P}$ deficient lowlands when resources are limited. 


\section{Highlights:}

33 - Combinations of $\mathrm{P}$ and water management options were tested in $\mathrm{P}$ deficient lowlands

34 - Root development of rice can be modified by specific P- but mainly by water management

35 - Under P limitation, reduced irrigation enhances rice development, P uptake, and yield

36 - Micro-dose placements can reverse P depletion in deficient lowlands

37 - For small P placement rates, interactions with water management should be considered

38

39 Key words: Water Saving Technologies, Phosphorus Efficiency, P Micro-dosing, P Placement, Alternate

40 Wetting and Drying, Aerobic Rice, Root Plasticity, Root Architecture

41 
43 In large parts of sub-Saharan Africa (SSA), rice (Oryza spp.) serves as an important staple crop. Population 44 growth and urbanization drastically increase rice consumption and demand. Rice production should 45 concomitantly increase to reduce dependence on rice imports, which endangers food security in many 46 African countries (Saito et al., 2015; van Oort et al., 2015). The total rice production in SSA has increased

47 during the last decades, but this mainly resulted from area expansion rather than system intensification 48 on existing farmland (FAOSTAT, 2018). There is a strong need for intensification on the existing rice 49 growing areas in SSA and a more efficient use of the available resources such as water and nutrients is a 50 prime requirement to achieve such sustainable intensification. (Saito et al., 2013; van Oort et al., 2015;

51 Zenna et al., 2017)

52 Drought and low phosphorus (P) availability are two major yield limiting factors in both upland and 53 lowland rice growing areas. As lowlands are among the most productive rice growing areas in SSA (Zenna 54 et al., 2017), optimization of management practices in P deficient and/or drought prone lowland systems offers major opportunities for further improvement of resource use and rice production (Becker et al., 56 2003; Nhamo et al., 2014).

57 In view of declining P resources (Schachtman et al., 1998; Zapata et al., 2004), more efficient P application methods have been developed for several crops (Nziguheba et al., 2016), but none are widely adopted in rice systems of SSA. Current low P fertilizer recovery rates and persistently low purchasing power of many 60 smallholder rice farmers preclude a drastic improvement of $P$ use in rice based systems. As $P$ is rather 61 immobile in soils, localized P applications form an option towards sustainable P management (Malhi et 62 al., 2001; Margenot et al., 2016; Nziguheba et al., 2016). A P micro-dose placement implies a very localized 63 application of a small P dose to a small surface or sub-surface area, often combined with seeds into the 64 planting hole (ICRISAT, 2009; Nkebiwe et al., 2016; Vandamme et al., 2018). This technique of P micro- 
dose placement is successfully tested and adopted for several cereal crops (Aune and Bationo, 2008; Bagayoko et al., 2011; Bielders and Gérard, 2015; Camara et al., 2013; van der Eijk, 2006). However, the technique of P micro-dose placement in direct seeded rice systems has only been studied and evaluated in a few cases (Bayan and Lourduraj, 2000; Garrity et al., 1990; Vandamme et al., 2018) and, to our knowledge, it is only adopted in upland rice growing areas of Madagascar (Andriamananjara et al., 2018; Raboin et al., 2014). The P micro-dose placement was observed to strongly benefit shoot growth and yield in direct seeded rice systems (Vandamme et al., 2018), but little is known about the effects on root performance and the interactions with water management in lowlands.

With an increasing prevalence of dry spells, it also becomes critical to optimize water use for rice production. Because of the huge water requirements of conventionally flooded rice, water saving technologies have been developed to help farmers cope with water scarcity and to increase water productivity in lowland rice systems (Bouman et al., 2007; de Vries et al., 2010). With alternate wetting and drying (AWD) the field is only irrigated up to flooding after the soil water table drops below a certain level beneath the soil surface $(-30 \mathrm{~cm}$ for normal AWD and $-15 \mathrm{~cm}$ for safe AWD) (Carrijo et al., 2017; LaHue et al., 2016), and hence the field is not continuously flooded. Another water saving approach aims to permanently maintain the soil close to field capacity, while never flooding the soil ('aerobic rice') (Bouman et al., 2005). Such promising water saving technologies are mainly developed and adopted in Asia, but are not yet widespread in lowlands of SSA.

Reduced water supply theoretically reduces P mobility in soils due to reduced effective diffusion (Kirk et al., 1990). However, reduced water availability largely influences root development and an improved root functioning may counteract a reduced P supply (De Bauw et al., 2019; Sandhu et al., 2017; Zhan et al., 2014). Similarly, several root characteristics may respond to a reduced $P$ supply, hence the combination of $\mathrm{P}$ and water management techniques may lead to differences in root performance, rice development, and yield (Kirk et al., 1998). De Bauw et al. (2019) previously examined how rice roots respond to several 
combinations of $\mathrm{P}$ and water availability, and showed that water availability has a dominant modifying

90 role on root architecture, in turn affecting P uptake efficiency. Understanding root plasticity under specific combinations of $\mathrm{P}$ and water management is thus important in efforts towards enhancing resilience to

92 both stresses. There is an urgent need to evaluate water saving technologies and P placement methods

93 with due attention to treatment effects on root architecture, before recommending these methods as 94 sustainable intensification strategies.

95 This work aims to 1) evaluate rice establishment, shoot growth, and yield under combined $\mathrm{P}$ and water management options in P deficient lowlands; more particularly focusing on the technique of P micro-dose

97 placement 2) examine rice root development, root architecture, and rooting patterns under such management techniques; 3) assess the residual effects of such intensification options on rice production

99 in P deficient lowlands. To this end, a two-year field experiment was conducted in a lowland field in 100 Tanzania with factorial combinations of water supplies (field capacity, alternating wetting drying, 101 permanent flooding) and $\mathrm{P}$ application (control, placements, and broadcast) in year 1 (field experiment

102 1). This was repeated in year 2 (field experiment 2), thereby testing residual effects. A trial in large pots 103 was additionally performed with equivalent treatments and allowing measurements of soil solution 104 composition, fertilizer effectiveness, and root density versus depth. Finally, P diffusion modelling 105 outwards of the fertilizer granules was performed to assist the interpretation of the field data.

\section{$107 \quad$ Materials and Methods}

\section{Field experiment 1}

109 A field trial was conducted at a lowland site in Morogoro (6 $6^{\circ} 50^{\prime} 31.4^{\prime \prime S}, 37^{\circ} 38^{\prime} 36.5^{\prime \prime} \mathrm{E}$; Tanzania) between 110 May and October 2017. Both irrigation and drainage was ensured. Site and soil information is presented 111 in Table 1. 
112 A split-plot design with three replicate blocks was set up with different levels of water supply in the main

113 plots and different P management treatments in the sub plots within each main plot. The size of the sub

114 plots was $3.6 \times 2.0 \mathrm{~m}$. Replicate blocks and main plots were separated at a distance of $2 \mathrm{~m}$ and a plastic

115 sheet was dug into the soil down to $50 \mathrm{~cm}$ in order to prevent horizontal water flow between water

116 treatments and replicate blocks. Within each main plot, sub plots were levelled and separated by bunds

117 and furrows at a distance of $50 \mathrm{~cm}$. Water management comprised three levels (field capacity (FC),

118 alternate wetting and drying (AWD), permanent flooding (PF)) while P management included four levels

119 (a control (NoP), placement at a rate of $3.45 \mathrm{~kg} \mathrm{P} \mathrm{ha}^{-1}$ (MicroP1), placement at a rate of $6.90 \mathrm{~kg} \mathrm{P} \mathrm{ha}^{-1}$

120 (MicroP2), and a basal broadcast of $25 \mathrm{~kg} \mathrm{P} \mathrm{ha}^{-1}$ (PlusP)).

121 Two seeds of the typical lowland rice variety NERICA-L-19 were sown at a distance of $20 \times 20 \mathrm{~cm}$. NERICA-

122 L-19 is an interspecific rice variety developed by the Africa Rice Center, using crosses between Oryza sativa

123 (Asian rice) and Oryza glaberrima (African rice). Before Triple Super Phosphate (TSP) was placed in the

124 planting hole, the TSP fertilizer was first sieved in order to homogenize granule size (1.5 mm radius). For

125 the plots with P placement (MicroP1 and MicroP2), three or six TSP granules (respectively $3.45 \mathrm{~kg} \mathrm{P} \mathrm{ha}^{-1}$

126 and $\left.6.90 \mathrm{~kg} \mathrm{P} \mathrm{ha}^{-1}\right)$ were first placed into each planting hole ( $2.5 \mathrm{~cm}$ depth) and covered with soil before

127 sowing ( $1 \mathrm{~cm}$ depth). In the plots with broadcast P (PlusP), TSP was broadcast at a conventional rate of 25

$128 \mathrm{~kg} \mathrm{P} \mathrm{ha}^{-1}$ at 17 days after sowing (DAS).

129 At 17 DAS, all plots were also amended with a first basal application of urea, muriate of potash (MOP), $130 \mathrm{MgSO}_{4}, \mathrm{ZnSO}_{4}$, and $\mathrm{H}_{3} \mathrm{BO}_{3}$ at rates of $34 \mathrm{~kg} \mathrm{Nha}^{-1}, 17 \mathrm{~kg} \mathrm{Kha}^{-1}, 21 \mathrm{~kg} \mathrm{Mg} \mathrm{ha}^{-1}, 27 \mathrm{~kg} \mathrm{Sha}^{-1}, 3 \mathrm{~kg} \mathrm{Zn} \mathrm{ha}^{-1}$, and $1312 \mathrm{~kg} \mathrm{~B} \mathrm{ha}^{-1}$ in order to avoid any nutrient deficiency other than P. Two top dressings of urea (34 kg N ha-1) 132 and MOP $\left(17 \mathrm{~kg} \mathrm{~K} \mathrm{ha}^{-1}\right)$ were later applied at 34 and 50 DAS. 
Table 1. Soil characteristics of soil from pot and field experiments.

\begin{tabular}{|c|c|c|c|c|c|c|c|c|c|c|}
\hline Trials & Location & Coordinates & pH & $\mathrm{Al}_{\text {ox }}$ & $\mathrm{Fe}_{\text {ox }}$ & $\mathrm{Mn}_{\mathrm{ox}}$ & $\mathbf{P}_{\text {ox }}$ & \multicolumn{3}{|c|}{----Texture---- } \\
\hline & & & & {$\left[\mathrm{mg} \mathrm{kg}^{-1}\right]$} & {$\left[\mathrm{mg} \mathrm{kg}^{-1}\right]$} & {$\left[\mathrm{mg} \mathrm{kg}^{-1}\right]$} & {$\left[\mathrm{mg} \mathrm{kg}^{-1}\right]$} & [\%sand] & [\%silt] & [\%clay] \\
\hline (a) Lowland field trials & $\begin{array}{c}\text { Morogoro, } \\
\text { Tanzania }\end{array}$ & $\begin{array}{c}6^{\circ} 50^{\prime} 31.4^{\prime \prime S} \\
37^{\circ} 38^{\prime} 36.5^{\prime \prime} \mathrm{E}\end{array}$ & $\begin{array}{l}6.6\left(\mathrm{CaCl}_{2}\right. \\
\mathrm{S} / \mathrm{W}=1: 5)\end{array}$ & 1193 & 2010 & 317 & 50 & 18 & 56 & 26 \\
\hline $\begin{array}{l}\text { (b) Soil for pot trial } \\
\text { Jan. } 2017\end{array}$ & $\begin{array}{l}\text { Dakawa, } \\
\text { Tanzania }\end{array}$ & $\begin{array}{l}06^{\circ} 23^{\prime} 56.6^{\prime \prime S} \\
37^{\circ} 33^{\prime} 47.5^{\prime \prime} \mathrm{E}\end{array}$ & $\begin{array}{l}6.7\left(\mathrm{CaCl}_{2} ;\right. \\
\mathrm{S} / \mathrm{W}=1: 5)\end{array}$ & 936 & 1848 & 532 & 22 & 9 & 62 & 29 \\
\hline
\end{tabular}


Plots were watered daily up to field capacity until 22 DAS. Then contrasting water regimes were imposed.

136 A water level of $5 \mathrm{~cm}$ was maintained in the PF treatment. For the AWD and FC treatments, perforated

137 PVC tubes (10 cm diameter, $30 \mathrm{~cm}$ length) were installed in each plot to monitor the soil water table.

138 Under AWD, plots were re-irrigated to flooding (water level at $5 \mathrm{~cm}$ ) when the water table dropped below

$139-15 \mathrm{~cm}$. Under FC, it was ensured that the soil water table never rose above $-20 \mathrm{~cm}$. Water management

140 was maintained daily until the end of the trial.

141 The dates of $85 \%$ and $100 \%$ maturity were noted. At 100 DAS, four adjacent rows were demarcated and 142 four representative plants (based on the average tiller number and plant height) were selected for further 143 shoot and root analysis. The shoots were cut, oven dried $\left(60^{\circ} \mathrm{C}\right)$, weighed, and manually ground by mortar. $144 \mathrm{P}$ concentrations in the shoot tissues $\left(\mathrm{Pc}_{\text {shoot }}\right)$ were then determined by ICP-OES (Thermo Scientific iCAP 1457000 series) after digestion in $\mathrm{HNO}_{3}$. Immediately after cutting the shoots, the root system of each 146 selected plant was excavated by digging out a block of soil around the stem $(20 \times 20 \times 20 \mathrm{~cm})$. The root 147 system was carefully washed out by gently shaking the block on a $2 \mathrm{~mm}$ net in water and subsequently 148 placed in a dish with clean water. The number of nodal roots was counted and the average nodal root 149 thickness was measured using a transparent ruler. Lateral root density and secondary branching degree were determined as described by De Bauw et al. (2019). Lateral root thickness (both at the root base and 151 for deeper roots) was scored according to five classes described in Table S1 (Supplementary Information). 152 After root analysis, the root system was oven dried and weighed. The P uptake in the shoot per unit root weight (Pup root) and per nodal root (Pup nodal) was calculated to provide estimators for P uptake efficiency.

154 At maturity, grain yield was determined in a net plot of $2.2 \times 1.6 \mathrm{~m}$ ( 88 hills), excluding border rows and rows used for root analysis. Grain yield is reported at a moisture content of $14 \%$. Agronomic P efficiency at harvest was calculated as $\mathrm{AEP}_{\text {grain }}=($ grain yield with $P$-grain yield without $P) /$ amount of $P$ applied. The

$157 \mathrm{P}$ concentrations in the grains ( $\mathrm{Pc}$ grains $)$ was determined by ICP-OES after digestion in $\mathrm{HNO}_{3}$. The seasonal $158 \quad P$ balance per hectare was calculated as: $P_{\text {balance }}=(P$ input by fertilizer $-P$ export by grain harvest $)$. 
Field experiment 2

161 In order to assess residual P effects and the consistency of treatment effects, a second trial was conducted 162 between May and October 2018. The same plots were used with the same P micro-dose rates as in the 163 previous season (2017) and established exactly in the same way. Control plots from 2017 were kept as a 164 control in 2018. In order to assess the residual P effects from a former broadcast, the plots amended with $16525 \mathrm{~kg} \mathrm{ha}^{-1}$ in 2017 were split in 2018 and half of each plot was sown as a control without P application (P0) 166 while the other half was amended with a placement of $6.90 \mathrm{~kg} \mathrm{ha}^{-1}$ (MicroP3). Water treatments were 167 implemented in the same way as during the first season.

168 Plant establishment, grain yield, agronomic $\mathrm{P}$ efficiency, and $\mathrm{P}$ balances were monitored and calculated 169 as described for the first season. Root data were not collected.

172 A pot trial with P deficient soil in large pots $(10.5 \mathrm{~L})$ was set up in the greenhouse with four levels of water 173 supply and four P management treatments and five replicates of each combination $(n=80)$. The water 174 treatments included drying periods (DP), field capacity (FC), safe-alternate wetting and drying (AWD), and 175 permanent flooding (PF); while $\mathrm{P}$ treatments included no application (NoP), a micro-dose $\mathrm{P}$ placement 176 (MicroP), suboptimal basal application (SubP), and a non-limiting basal application (PlusP).

177 The trial was conducted in a greenhouse located at Sokoine University of Agriculture in Morogoro $178 \quad\left(6^{\circ} 50^{\prime} 53.9^{\prime \prime} \mathrm{S}, 37^{\circ} 39^{\prime} 31.3^{\prime \prime} \mathrm{E}\right.$; Tanzania). Average daily minimum and maximum temperatures during the 179 experiment were respectively 21.9 and $33.4^{\circ} \mathrm{C}$. 
180

181

182

Initially, a P-deficient soil ( $\mathrm{P}<0.01 \mathrm{mg} \mathrm{L}^{-1}$ in solution) was collected from a lowland rice field in Dakawa, Tanzania (Table 1). After sampling, the bulk soil was shade dried, crushed to an aggregate size of $4 \mathrm{~mm}$, and amended with salts of $\mathrm{NH}_{4} \mathrm{NO}_{3}, \mathrm{CaCl}_{2}, \mathrm{MgSO}_{4}, \mathrm{ZnSO}_{4}, \mathrm{CuSO}_{4}, \mathrm{H}_{3} \mathrm{BO}_{3}$ and $\mathrm{Na}_{2} \mathrm{MoO}_{4}$ at rates of $37 \mathrm{mg} \mathrm{N}$ $\mathrm{kg}^{-1}, 95 \mathrm{mg} \mathrm{K} \mathrm{kg}{ }^{-1}, 15 \mathrm{mg} \mathrm{Mg} \mathrm{kg}{ }^{-1}, 20 \mathrm{mg} \mathrm{S} \mathrm{kg}^{-1}, 2.5 \mathrm{mg} \mathrm{Zn} \mathrm{kg}^{-1}, 0.04 \mathrm{mg} \mathrm{B} \mathrm{kg}^{-1}, 0.08 \mathrm{mg} \mathrm{Cu} \mathrm{kg}{ }^{-1}$, and 0.034 $\mathrm{mg} \mathrm{Mo} \mathrm{Kg}{ }^{-1}$ soil, to avoid any nutrient deficiency other than $\mathrm{P}$.

To mimic a P deficient subsoil, no P was initially added to this bulk soil. Eighty large pots (height: $52 \mathrm{~cm}$, diameter: $16 \mathrm{~cm}$ ) were first filled with $6.8 \mathrm{~kg}$ of this $\mathrm{P}$ deficient soil $(28.5 \mathrm{~cm}$ in pot height). To avoid downwards $\mathrm{P}$ transport by wetting the whole pot at once, each pot with this layer of subsoil was first watered to field capacity $(38 \% \mathrm{w} / \mathrm{w})$ before adding the topsoil. Pots of flooded treatments (PF) were sealed at the bottom. The remainder of the soil was used to create three different topsoils by subjecting them to different $P$ treatments. One fourth was amended with a non-limiting amount of ground TSP (63.1 $\mathrm{mg} \mathrm{P} \mathrm{kg}$ topsoil $^{-1}$ or $280 \mathrm{mg} \mathrm{P}$ per pot) up to a theoretical $\mathrm{P}$ concentration of $0.4 \mathrm{mg} \mathrm{P} \mathrm{L}^{-1}$ in soil solution, representing a non-limiting basal broadcast (PlusP). Another quarter was amended with a sub-optimal amount of ground TSP (18.6 mg P kg topsoil or $82 \mathrm{mg} \mathrm{P}$ per pot) up to a theoretical $\mathrm{P}$ concentration of 0.1

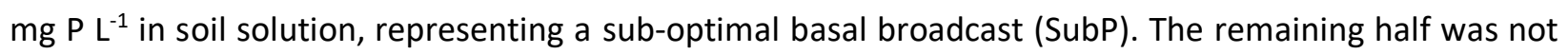
amended with TSP and was later divided into two treatments (NoP and MicroP). The same amount of Ca was added in all treatments by using $\mathrm{CaCl}_{2}$. Pots were subsequently filled with $4.4 \mathrm{~kg}$ of these topsoils and the whole pot was watered to field capacity.

A pre-germinated seed of NERICA-L-19 was sown in each pot. For the treatment with micro-dose $P$ placement (MicroP), $0.12 \mathrm{~g}$ TSP (24 mg P pot ${ }^{-1}$ ) was first applied in the planting hole of the non-amended topsoil before sowing. This placement rate corresponds with a micro-dose rate of $6 \mathrm{~kg} \mathrm{ha}^{-1}$ when plants are conventionally spaced at $20 \times 20 \mathrm{~cm}$. Two top dressings of $\mathrm{NH}_{4} \mathrm{NO}_{3}$ (in solution) were applied at a rate 
of $323 \mathrm{mg} \mathrm{N}$ per pot at 21 and $34 \mathrm{DAS}$. Additional top dressings of $\mathrm{ZnSO}_{4}, \mathrm{KCl}$, and $\mathrm{MgSO} 4$ were added at 21 DAS to each pot at rates of $0.37 \mathrm{~g} \mathrm{Zn}, 1.4 \mathrm{~g} \mathrm{~K}$, and $0.12 \mathrm{~g} \mathrm{Mg}$, to avoid deficiency of these nutrients.

Water treatments were initiated at 17 DAS and were maintained and monitored on a daily basis until the end of the trial. In the treatment with permanent flooding (PF), a water layer of $5 \mathrm{~cm}$ above soil level was maintained. For the safe-alternate wetting and drying treatment (AWD), the soil water level was monitored by perforated tubes with diameter of $1.5 \mathrm{~cm}$, and pots were re-irrigated when the water table dropped below $15 \mathrm{~cm}$. Pots were watered daily up to field capacity for the treatment with field capacity (FC) while in the last treatment, pots were only re-watered up to field capacity with intervals of ca. six days to represent drying periods (DP) during erratic rainfall.

Plant development was monitored by measuring plant height and counting tillers and leaves twice a week. To monitor $\mathrm{P}$ concentration in the soil pore water, rhizon samplers $(10 \mathrm{~cm}$ length, $2.5 \mathrm{~mm}$ diameter, 0.15 $\mu \mathrm{m}$ pore size) were installed in each pot at a distance of $4 \mathrm{~cm}$ from the seedling (and P placement). Soil pore water samples were taken at a frequency of seven days, during the whole experiment.

At 49 DAS, shoots were cut and analyzed as described for the field experiment. Immediately after removing the shoot, the soil cylinder was carefully taken out of the pot and precisely cut into three segments. One part comprised a segment from 0 to $15 \mathrm{~cm}$ depth which included the 'basal roots', another segment comprised soil from 15 to $30 \mathrm{~cm}$ depth including the 'intermediate roots', and the last segment between 30-52 cm incorporated the 'deep roots'. The latter segment was defined according to most rice studies, where deep roots are defined as roots below $30 \mathrm{~cm}$ (Gowda et al., 2011; Kato et al., 2013, 2006). For each soil segment, roots were carefully washed out by using water and nets ( $2 \mathrm{~mm}$ size). After removing the soil, roots of each segment were placed in a dish with clean water and root architectural variables were determined as described for the field experiment. 
224 The root segments were oven dried $\left(60^{\circ} \mathrm{C}\right)$ and weighed to determine root distribution and biomass

225 allocation. The P uptake efficiency parameters (Pup root, $_{\text {Pup }}$ (a) ) were subsequently calculated. A 226 provisional indicator of the agronomic efficiency of the $P$ fertilizer at 49 DAS was calculated as AEP $49 \mathrm{DAS}=$

227 (straw mass with $P$ - straw mass without $P$ )/ amount of $P$ applied.

\section{Data analysis}

229 All statistics were computed in R version 3.4.1. (R Development Core Team 2012) and the level of 230 significance to detect effects was set at $p=0.05$. Two-way ANOVAs were performed on the shoot and root 231 variables with water and P treatments as fixed effects. Replicate pots or blocks were included as random

232 effects. Means $(\mu)$ and standard errors of the mean $\left(\frac{\sigma}{\sqrt{n}}\right.$, with $\sigma=$ standard deviation and $n=$ the number 233 of observations) were calculated for all treatment combinations and significance between treatment 234 means was determined by calculating the Least Significant Difference, after confirming normality of the 235 residuals.

\section{Modeling $\mathbf{P}$ diffusion, adsorption and availability of placed $\mathbf{P}$ under different water regimes}

238 Given the strong interaction between soil moisture and $\mathrm{P}$, this section aims to assess the physical and 239 chemical influences through diffusion and sorption of contrasting water management on P availability 240 under several placement rates. The P diffusion outwards $\mathrm{P}$ fertilizer granules was modelled to interpret 241 the results. Locally placed $\mathrm{P}$ in soils generally moves away from the point of application through diffusion, 242 while sorption and precipitation reactions may reduce P mobility (Degryse and McLaughlin, 2014). The 243 diffusion from micro-dose P placements was modelled using the spherical diffusion model described by 244 Degryse and McLaughlin (2014):

$$
\frac{\delta c}{\delta t}+\frac{\rho \delta\left(k c^{n}\right)}{\theta \delta t}=f \frac{D}{r^{2}} \frac{\delta}{\delta r}\left(r^{2} \frac{\delta c}{\delta r}\right)
$$


246

247

248

249

250

251

252

253

254

255

256

257

258

259

260

261

262

263

264

265

266

267

268

With $c$ the $\mathrm{P}$ concentration in soil solution $\left(\mathrm{mg} \mathrm{L}^{-1}\right), \rho$ the bulk density $\left(\mathrm{kg} \mathrm{L}^{-1}\right), \theta$ the volumetric water content, $f$ the tortuosity factor, $D$ the diffusion coefficient in water $\left(\mathrm{cm}^{2} \mathrm{~s}^{-1}\right), r$ the radial distance $(\mathrm{cm})$, and $t$ the time (s). The $\mathrm{P}$ sorption was accounted for by the Freundlich parameters $(k$ and $n)$. Soil parameters $(k, n, \rho)$ were determined for the $\mathrm{P}$ deficient lowland soil from the field trial, for which $\theta$ was altered between field capacity $(\mathrm{pF}=2)$ and soil saturation $(\mathrm{pF}=0)$.

The $\mathrm{P}$ sorption $(k$ and $n)$ can theoretically change under altered water availability due to reduction/oxidation of iron oxides. However, when the molar $\mathrm{P} /$ Fe ratio (oxalate extracted) of a soil is low $(<0.12$; i.e. $\mathrm{P}$ deficiency), it has been shown that there is no additional $\mathrm{P}$ release under anaerobic conditions (Smolders et al., 2017), and this assumption is confirmed by the soil solution data (data not shown). Under $\mathrm{P}$ deficiency the Freundlich parameters ( $k$ and $n$ ) thus remain constant under both soil saturation and field capacity. The $\mathrm{k}$ and $\mathrm{n}$ parameters were derived from a $\mathrm{P}$ adsorption experiment. Briefly, the topsoil of the field experiment was dried and sieved. Replicate samples of $3 \mathrm{~g}$ were suspended in $30 \mathrm{~mL}$ water and amended with $\mathrm{KH}_{2} \mathrm{PO}_{4}$ at various rates between 0-60 $\mathrm{mg} \mathrm{P} \mathrm{L}^{-1}$. The soils were equilibrated end-over-end for $24 \mathrm{~h}$ followed by centrifugation and filtration $(0.45 \mu \mathrm{m})$ and analyzed of $\mathrm{P}$ by Inductively Coupled Plasma Mass Spectrometry (ICP-MS, Agilent7700X). The value of k was $180 \mathrm{mg}^{0.3}$ $\mathrm{L}^{0.7} \mathrm{~kg}^{-1}$ and $\mathrm{n}$ was 0.7 .

The fertilizer was described as a sphere of $2.18 \mathrm{~mm}$ radius containing $12 \mathrm{mg} \mathrm{P}$ or $2.74 \mathrm{~mm}$ containing 24 $\mathrm{mg} \mathrm{P}$, corresponding with application rates of 3 and $6 \mathrm{~kg} \mathrm{ha}^{-1}$ respectively. In this model, $\mathrm{P}$ uptake by plants during diffusion was not incorporated as this section focuses on the P availability through soil processes and management only. For P deficient soils, the initial P concentration in soil solution was assumed to be $0 \mathrm{mg} \mathrm{L}^{-1}$, as the measured concentration in the control soil was $<0.03 \mathrm{mg} \mathrm{L}^{-1}$. The $\mathrm{P}$ diffusion over time was spherically modeled for the two placement rates and two water levels (field capacity and saturation) and 
269 the diffusion equation was numerically solved in Microsoft Excel using the initial and boundary conditions

270 as described in Degryse and McLaughlin (2014).

271

\section{Results}

$273 \quad$ Field experiment 1

274 Shoot development and grain yield

275 Without $\mathrm{P}$ application, plant development (height and number of tillers) was very slow, but it was 276 enhanced by maintaining the soil at FC compared to AWD and PF (Figure S1, Supplementary Information).

277 There was a significant interaction effect between water and P on shoot development. Shoot mass at 100

278 DAS strongly increased with P application. Shoot mass was similar for both micro-dose rates under FC but 279 for MicroP1, shoot growth (and also P uptake) was lower under AWD and PF compared to FC, while this 280 reduction was not significant for MicroP2. FC enhanced shoot biomass production compared to PF only 281 at NoP and MicroP1 (Table 2). The same trends were confirmed at harvest, i.e. grain yield was consistently 282 highest under FC for MicroP1 and NoP compared to other water treatments while these differences due 283 to water were absent at higher P applications (Micro P2 and PlusP) (Figure 1). P broadcast and micro284 dosing increased grain yields 7-fold and 3-fold respectively.

285 P application reduced the time needed to reach 85\% maturity, with an average of 143, 134, 133, and 131 286 days respective to the applied $\mathrm{P}$ rates (increasing order). Water management did not affect the duration 287 of the phenological stages. (Table 4) 


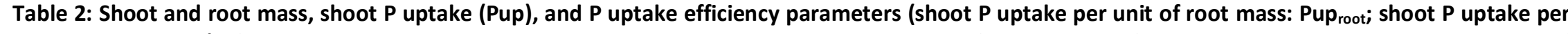
nodal root: Pup nodal $_{\text {) }}$ of rice at 100 DAS in Field Experiment 1. Rice plants were grown on a $P$ deficient lowland field that was subjected to combinations of water management options (field capacity (FC), safe alternate wetting and drying (AWD), and permanent flooding (PF)) and P management options (No P application (NoP), two rates of micro-dose placement (MicroP1 and MicroP2, respectively 3.45 and $6.90 \mathrm{~kg} \mathrm{P} \mathrm{ha}^{-1}$ ), and a conventional broadcast of $25 \mathrm{~kg} P$ $\mathrm{ha}^{-1}$ (PlusP)). Data are presented as means with (standard errors of the mean).

\begin{tabular}{|c|c|c|c|c|c|c|}
\hline \multicolumn{7}{|c|}{ Field experiment 1} \\
\hline $\mathbf{P}$ & Water & $\begin{array}{c}\text { Shoot } \\
\text { mass }\end{array}$ & $\begin{array}{l}\text { Root } \\
\text { mass }\end{array}$ & Pup & Pup root & Pup ${ }_{\text {nodal }}$ \\
\hline & & [g plant $^{-1}$ ] & [g plant $^{-1}$ ] & [mg plant $^{-1}$ ] & {$\left[\mathrm{mg} \mathrm{g}^{-1}\right]$} & {$\left[\mu \mathrm{g} \mathrm{nodal}^{-1}\right]$} \\
\hline \multirow[t]{3}{*}{ NoP } & FC & $4.4(0.6)$ & $2.1(0.2)$ & $3.1(0.6)$ & $1.43(0.16)$ & $23(3)$ \\
\hline & AWD & $2.7(0.6)$ & $1.2(0.2)$ & $1.2(0.3)$ & $1.11(0.10)$ & $13(2)$ \\
\hline & PF & $2.1(0.6)$ & $1.2(0.3)$ & $0.9(0.2)$ & $0.80(0.09)$ & $9(1)$ \\
\hline \multirow[t]{3}{*}{ MicroP1 } & FC & $16.7(1.1)$ & $6.2(0.5)$ & $8.3(0.6)$ & $1.47(0.14)$ & $37(2)$ \\
\hline & AWD & $8.6(0.8)$ & $4.9(0.6)$ & $4.1(0.5)$ & $0.95(0.17)$ & $22(2)$ \\
\hline & PF & $9.2(0.5)$ & $4.8(0.4)$ & $4.4(0.5)$ & $0.92(0.06)$ & $20(1)$ \\
\hline \multirow[t]{3}{*}{ MicroP2 } & FC & $15.5(1.1)$ & $6.1(0.4)$ & $7.6(0.6)$ & $1.32(0.15)$ & $33(2)$ \\
\hline & AWD & $14.6(1.4)$ & $6.9(0.6)$ & $7.0(0.7)$ & $1.04(0.10)$ & $30(2)$ \\
\hline & PF & $12.9(0.9)$ & $7.2(0.6)$ & $6.4(0.6)$ & $0.91(0.07)$ & $26(2)$ \\
\hline \multirow[t]{6}{*}{ PlusP } & FC & $35.6(2.5)$ & $10.9(0.8)$ & $25.8(2.8)$ & $2.42(0.25)$ & $83(7)$ \\
\hline & AWD & $33.6(3.4)$ & $10.6(1.2)$ & $19.9(2.0)$ & $1.94(0.16)$ & $61(3)$ \\
\hline & PF & $39.1(2.4)$ & $12.5(0.7)$ & $26.2(2.3)$ & $2.11(0.17)$ & $68(3)$ \\
\hline & water & ns & ns & ns & * & +** \\
\hline & $\mathbf{P}$ & $* * *$ & $* * *$ & $* * *$ & $* * *$ & $* * *$ \\
\hline & water $\times P$ & $*$ & ns & $(0.057)$ & $\mathrm{ns}$ & $\mathrm{ns}$ \\
\hline
\end{tabular}




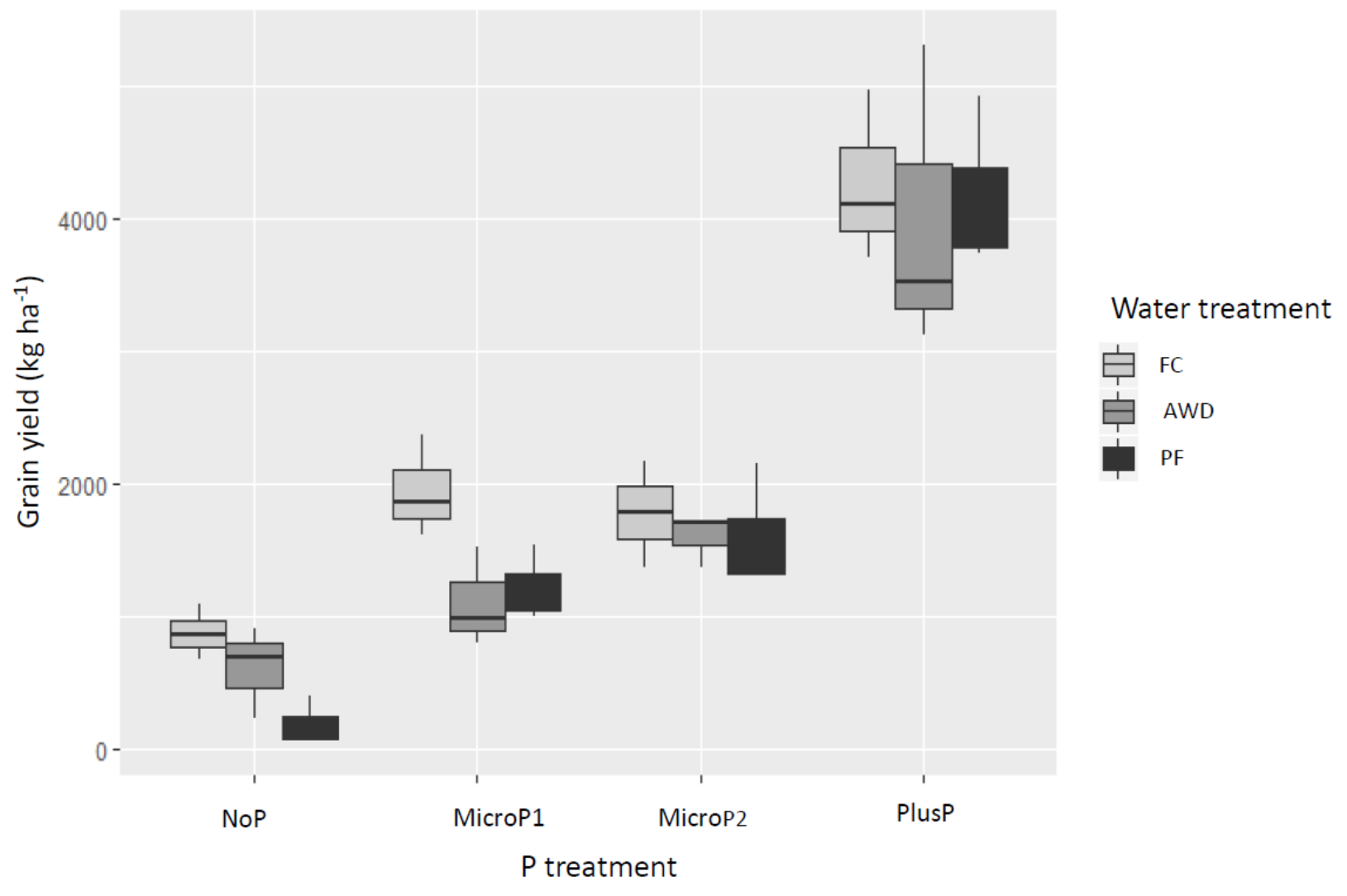

Figure 1: Grain yield of field grown lowland rice (field experiment 1; 2017) subjected to combinations of water management techniques (field capacity (FC), alternate wetting and drying (AWD), and permanent flooding (PF)) and $\mathrm{P}$ management options (No P application (NoP), two rates (3.45 and $6.90 \mathrm{~kg} \mathrm{P} \mathrm{ha}^{-1}$ ) of micro-dose placement (MicroP1 and MicroP2), and a conventional broadcast of $25 \mathrm{~kg} \mathrm{P} \mathrm{ha}^{-1}$ (Plus P). 
300 At 100 DAS, the nodal root thickness increased according to P application (NoP < MicroP1 and MicroP2 < 301 PlusP), and there was no significant difference between the two placement rates. Within each $P$ 302 application method, nodal root thickness reduced under FC, but it showed an opposite trend without P 303 amendment (Table 3).

304 Lateral root density at the nodal base was significantly highest for P placements and lowest under PlusP.

305 Reduced water use significantly reduced the basal lateral root density (FC<AWD<PF). (Table 3 )

306 The lateral thickness at the nodal base as also in deepest layers increased with reduced water use. Lateral

307 roots in deepest layers were thinner without P application. (Table 3)

308 Secondary branching degree at the nodal base was smallest without $\mathrm{P}$ application, and a similar trend was 309 observed for secondary branching in deepest layers. For these deep roots, secondary branching 310 consistently increased with reduced water application, but this trend was not observed for MicroP2. 311 (Table 3)

312 P uptake \& acquisition efficiency at 100 DAS

313 The $\mathrm{Pc}_{\text {shoot }}$ was consistently highest for PlusP and there was no difference in $\mathrm{Pc}_{\text {shoot }}$ between MicroP1 and 314 MicroP2. Without $\mathrm{P}$ application, $\mathrm{Pc}_{\text {shoot }}$ significantly increased with reduced water use. $\mathrm{P}$ application 315 increased total $\mathrm{P}$ uptake, and without $\mathrm{P}$ application this $\mathrm{P}$ uptake increased with reduced water 316 application. The shoot $\mathrm{P}$ uptake under placement was similar for both rates under FC, however the $\mathrm{P}$ 317 uptake under FC was larger than under AWD and PF at the MicroP1 while it was unaffected by water 318 treatment at MicroP2. (Table S2, Supplementary Information) 
Table 3: Architectural root variables of field grown rice at $100 \mathrm{DAS}$. The field was subjected to combinations of water management techniques (field capacity (FC), safe alternate wetting and drying (AWD), and permanent flooding (PF)) and P management strategies (No P application (NoP), two rates of micro-dose placement (MicroP1 and MicroP2, respectively 3.45 and $6.90 \mathrm{~kg} \mathrm{P} \mathrm{ha}^{-1}$ ), and a conventional broadcast of $25 \mathrm{~kg} \mathrm{P}^{-1}$ (PlusP)). Lateral root thickness and secondary branching were determined for the nodal root base, but also for the deepest roots. Data are presented as means with (standard errors of the mean).

\begin{tabular}{|c|c|c|c|c|c|c|c|}
\hline \multicolumn{8}{|c|}{ Field experiment 1} \\
\hline \multirow[t]{3}{*}{$P$} & Water & $\begin{array}{l}\text { Nodal } \\
\text { thickness }\end{array}$ & $\begin{array}{l}\text { Lateral } \\
\text { root } \\
\text { density }\end{array}$ & $\begin{array}{l}\text { Lateral } \\
\text { root } \\
\text { thickness }\end{array}$ & $\begin{array}{l}\text { Secondary } \\
\text { branching }\end{array}$ & $\begin{array}{l}\text { Lateral } \\
\text { root } \\
\text { thickness }\end{array}$ & $\begin{array}{l}\text { Secondary } \\
\text { branching }\end{array}$ \\
\hline & & \multicolumn{4}{|c|}{ 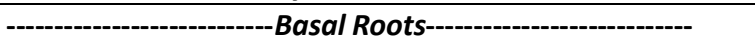 } & \multicolumn{2}{|c|}{------Deep Roots------- } \\
\hline & & {$[\mathrm{mm}]$} & [score] & [score] & [score] & [score] & [score] \\
\hline \multirow[t]{3}{*}{ NoP } & FC & $0.80(0.03)$ & $5.2(0.16)$ & $1.88(0.15)$ & $2.5(0.3)$ & $3.2(0.2)$ & $3.4(0.2)$ \\
\hline & AWD & $0.70(0.05)$ & $6.1(0.15)$ & $1.29(0.12)$ & $2.0(0.2)$ & $2.1(0.3)$ & $2.3(0.2)$ \\
\hline & PF & $0.64(0.06)$ & $6.8(0.22)$ & $1.08(0.06)$ & $2.3(0.3)$ & $1.7(0.3)$ & $1.8(0.2)$ \\
\hline \multirow[t]{3}{*}{ MicroP1 } & FC & $0.92(0.03)$ & $5.3(0.18)$ & $1.92(0.14)$ & $3.0(0.2)$ & $3.6(0.2)$ & $4.2(0.2)$ \\
\hline & AWD & $1.08(0.05)$ & $6.8(0.23)$ & $1.21(0.13)$ & $3.4(0.3)$ & $2.7(0.2)$ & $3.8(0.1)$ \\
\hline & PF & $1.08(0.05)$ & $7.0(0.20)$ & $1.00(0.00)$ & $3.0(0.3)$ & $2.1(0.1)$ & $3.2(0.2)$ \\
\hline \multirow[t]{3}{*}{ MicroP2 } & FC & $0.96(0.03)$ & $5.4(0.18)$ & $1.96(0.07)$ & $2.7(0.2)$ & $3.7(0.1)$ & $3.8(0.2)$ \\
\hline & AWD & $1.22(0.04)$ & $6.3(0.40)$ & $1.33(0.11)$ & $3.2(0.3)$ & $2.6(0.2)$ & $3.8(0.1)$ \\
\hline & PF & $1.17(0.06)$ & $6.8(0.20)$ & $1.04(0.04)$ & $3.1(0.2)$ & $2.0(0.2)$ & $3.6(0.3)$ \\
\hline \multirow[t]{6}{*}{ PlusP } & FC & $1.07(0.03)$ & $5.1(0.22)$ & $2.00(0.15)$ & $3.4(0.3)$ & $3.5(0.1)$ & $4.4(0.1)$ \\
\hline & AWD & $1.30(0.03)$ & $5.7(0.24)$ & $1.54(0.16)$ & $2.7(0.3)$ & $2.7(0.2)$ & $3.4(0.2)$ \\
\hline & PF & $1.35(0.03)$ & $6.2(0.25)$ & $1.17(0.09)$ & $3.1(0.2)$ & $2.1(0.3)$ & $3.3(0.2)$ \\
\hline & water & ** & $* * *$ & $* * *$ & ns & $* * *$ & ns \\
\hline & $\mathbf{P}$ & $* * *$ & $* * *$ & ns & $* * *$ & $* *$ & $* * *$ \\
\hline & water $\times \mathbf{P}$ & $* * *$ & ns & ns & ns & ns & $* * *$ \\
\hline
\end{tabular}


Table 4: Time (in days) needed to reach $85 \%$ maturity and the agronomic efficiency of the $P$ fertilizer (AEP) based on grain yield for both field experiment 1 and 2. Data are presented as means with (standard errors). A two-year field experiment was conducted in a lowland field in Tanzania with factorial combinations of water supplies (field capacity (FC), alternating wetting drying (AWD), permanent flooding (PF)) and P application (control (NoP, two rates of micro-dose placement (MicroP1 and MicroP2, respectively 3.45 and $6.90 \mathrm{~kg} \mathrm{P} \mathrm{ha}^{-1}$ ), and a broadcast (PlusP)) in year 1 (field experiment 1 ). This was repeated in year $\mathbf{2}$ (field experiment 2), thereby testing residual effects of a broadcast.

\begin{tabular}{|c|c|c|c|c|c|}
\hline \multirow[b]{2}{*}{$\mathbf{P}$} & \multirow{3}{*}{ Water } & \multicolumn{2}{|c|}{----Field experiment 1---- } & \multicolumn{2}{|c|}{----Field experiment 2---. } \\
\hline & & $\begin{array}{c}\text { Time to } \\
85 \% \\
\text { maturity }\end{array}$ & $\begin{array}{c}\text { AEP } \\
\text { At harvest }\end{array}$ & $\begin{array}{c}\text { Time to } \\
85 \% \\
\text { maturity }\end{array}$ & $\begin{array}{c}\text { AEP } \\
\text { At harvest }\end{array}$ \\
\hline & & [days] & {$\left[\mathrm{kg} \mathrm{kg}^{-1}\right]$} & [days] & {$\left[\mathrm{kg} \mathrm{kg}^{-1}\right]$} \\
\hline \multirow[t]{3}{*}{ NoP } & FC & 139 (3.4) & - & $145(2.0)$ & - \\
\hline & AWD & $145(1.2)$ & - & $149(0.0)$ & - \\
\hline & PF & $145(2.6)$ & - & $156(14.5)$ & - \\
\hline \multirow[t]{3}{*}{ MicroP1 } & FC & $134(0.7)$ & $310(45)$ & $138(0.7)$ & $395(48)$ \\
\hline & AWD & $136(1.2)$ & $144(28)$ & $138(0.6)$ & $489(68)$ \\
\hline & PF & $133(0.6)$ & $297(69)$ & $136(1.2)$ & $396(43)$ \\
\hline \multirow[t]{3}{*}{ MicroP2 } & FC & $133(0.7)$ & $130(44)$ & $137(0.0)$ & $178(26)$ \\
\hline & AWD & $132(0.9)$ & $143(37)$ & $135(1.0)$ & $320(59)$ \\
\hline & PF & $133(0.7)$ & $205(51)$ & $136(1.2)$ & $305(53)$ \\
\hline \multirow[t]{3}{*}{ PlusP } & FC & $132(0.9)$ & $136(10)$ & - & - \\
\hline & AWD & $131(0.6)$ & $135(23)$ & - & - \\
\hline & PF & $130(0.3)$ & $159(18)$ & - & - \\
\hline \multirow{3}{*}{$\begin{array}{l}\text { MicroP3 } \\
\text { Placement } 2 \\
\text { after PlusP in } 2017\end{array}$} & FC & - & - & $137(0.3)$ & $210(41)$ \\
\hline & AWD & - & - & $138(0.3)$ & $239(58)$ \\
\hline & PF & - & - & $138(0.3)$ & $201(42)$ \\
\hline \multirow{6}{*}{$\begin{array}{l}\text { PO } \\
\text { No P } \\
\text { after PlusP in } 2017\end{array}$} & FC & - & - & $144(1.0)$ & - \\
\hline & AWD & - & - & $143(1.5)$ & - \\
\hline & PF & - & - & $146(0.3)$ & - \\
\hline & water & ns & * & ns & $\mathrm{ns}$ \\
\hline & $\mathbf{P}$ & $* * *$ & $* *$ & $* * *$ & $* * *$ \\
\hline & water $\times \mathbf{P}$ & ns & $(0.068)$ & ns & ns \\
\hline
\end{tabular}


336 The Pup root was largest under PlusP. The Pup nodal showed a similar trend according to P application and

337 was smaller in the control than for both placement rates. Water management similarly affected both

338 efficiency parameters and P uptake efficiency was consistently largest under FC compared to that at larger

339 water supply. (Table 2)

340 Agronomic efficiency and P balance

341 The AEP grain of PlusP was similar as that for MicroP2. The AEPgrain was largest for MicroP1, only under FC

342 and PF (not for AWD). (Table 4)

343 The seasonal $\mathrm{P}$ balance was significantly affected only by the $\mathrm{P}$ treatments. Without fertilizer application,

344 the $\mathrm{P}$ balance was obviously negative (ca. $-0.6 \mathrm{~kg} \mathrm{P} \mathrm{ha}^{-1}$ ), while for Plus $\mathrm{P}$ the balance was strongly positive

345 (ca. $20.3 \mathrm{~kg} \mathrm{ha}^{-1}$ ). For MicroP1, the P balance was relatively close to zero (ca. $2.1 \mathrm{~kg} \mathrm{ha}^{-1}$ ), while the balance

346 for MicroP2 was fairly positive (ca. $5.2 \mathrm{~kg} \mathrm{ha}^{-1}$ ). (Figure 2)

$348 \quad$ Field experiment 2

349 Plant development was similar for all placements. Without P application, growth was enhanced in the 350 plots that were broadcasted in 2017 and benefits were observed from reduced irrigation (Figure S1, 351 Supplementary Information).

352 P application reduced the time needed to reach $85 \%$ maturity similarly for all placement rates compared

353 to both controls (Table 4). Without $P$ application, a residual $P$ effect from the former basal application 354 facilitated plant development. 

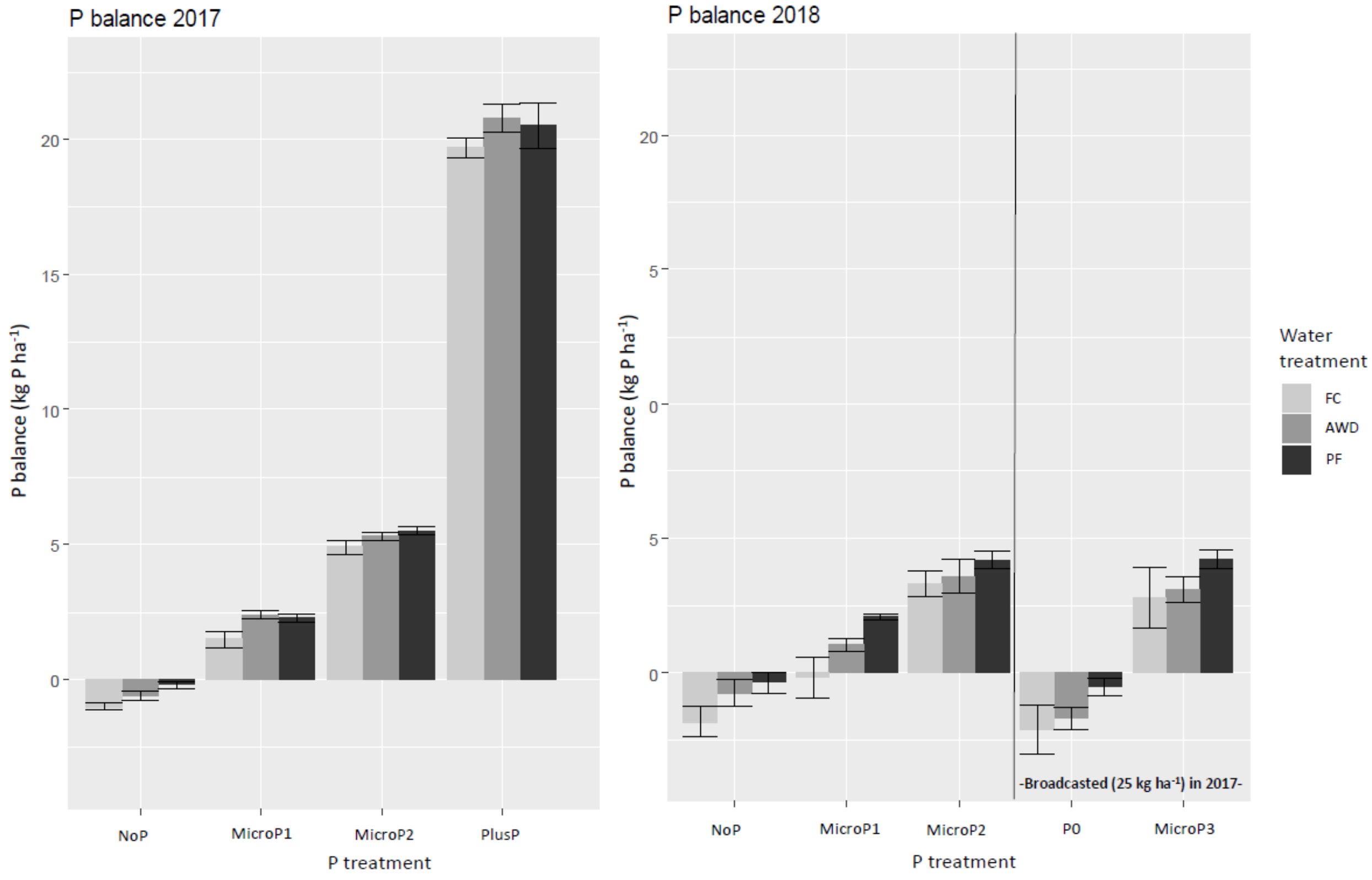

Figure 2: The seasonal P balance (kg P ha ${ }^{-1}$ ) for field experiment 1 (left panel) and 2 (right panel). Plots broadcasted (PlusP) in 2017 were split in 2018 and half of these plots were sown as a control without P fertilizer (P0) while the other half was amended with a P placement rate of $6.9 \mathrm{~kg} \mathrm{P} \mathrm{ha}^{-1}$. 
Grain yield (Figure 3) was consistently lower than the potential yield observed in the previous experiment.

357 The yield was significantly affected by both $\mathrm{P}$ and water management. There was a positive effect of the 358 residual $\mathrm{P}$, but the effect was only significant without $\mathrm{P}$ application ( $\mathrm{P} 0>\mathrm{NoP}$ ). PF consistently reduced yield compared to AWD and FC, and this negative effect was strongest for MicroP1 confirming results from the year 1 experiment. (Figure 3)

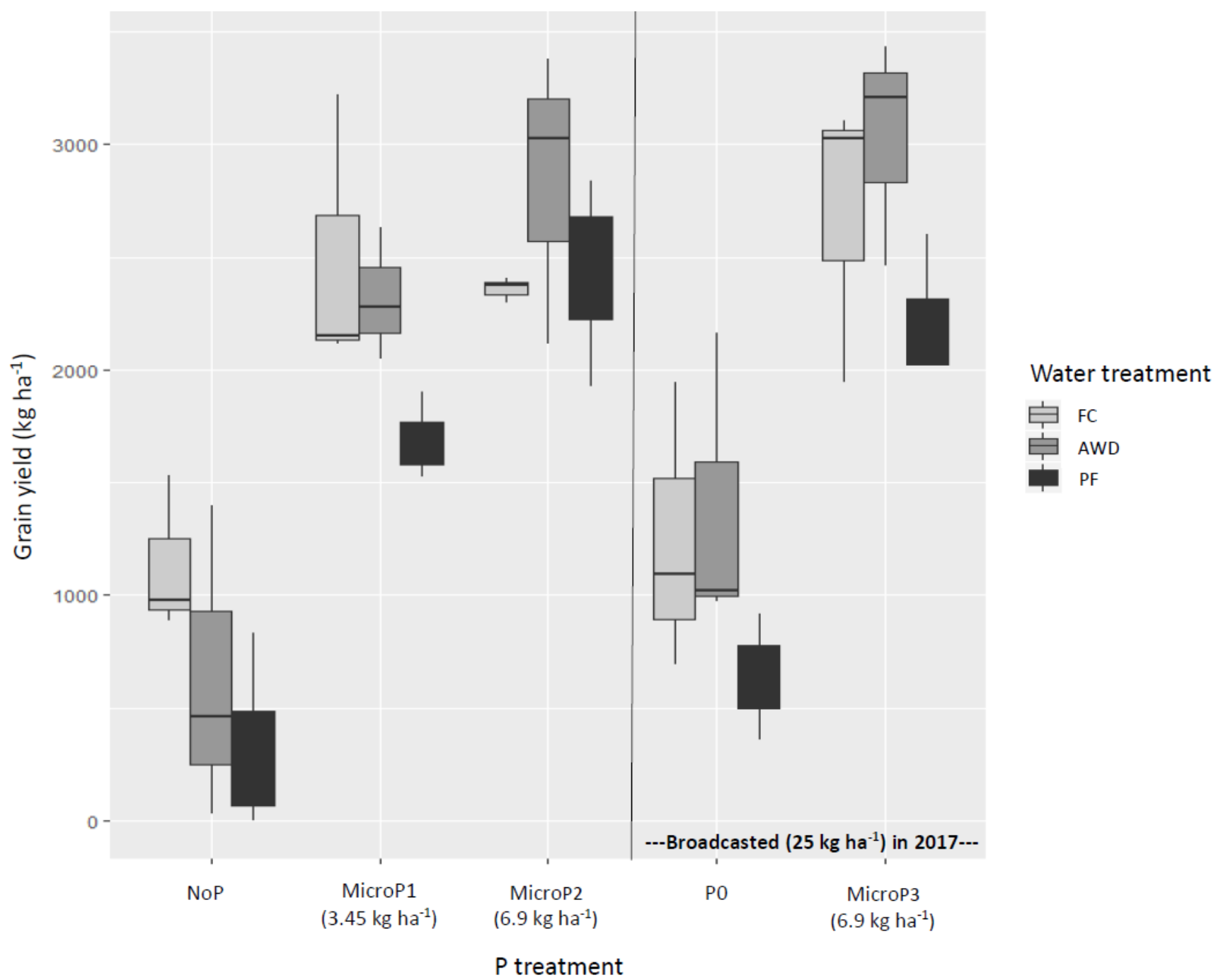

Figure 3: Grain yield of field grown lowland rice (field experiment 2; 2018) subjected to combinations of water management techniques (field capacity (FC), alternate wetting and drying (AWD), and permanent flooding (PF)) and P management options (No P fertilization (No P), two rates ( 3.45 and $6.90 \mathrm{~kg} \mathrm{P} \mathrm{ha}^{-1}$ ) of micro-dose placement (MicroP1 and MicroP2); Plots broadcasted with $25 \mathrm{~kg} \mathrm{P} \mathrm{ha}^{-1}$ in 2017 were split and half of each plot was kept as a control (P0) while the other half was amended with a micro-dose placement of $6.9 \mathrm{~kg} \mathrm{P} \mathrm{ha}^{-1}$ (MicroP3)). 
362 The $\mathrm{AEP}_{\text {grain }}$ was largest for MicroP1 and no residual P effect was observed for the highest placement

363 rate (MicroP2=MicroP3) (Table 4). Water treatment did not affect the $\mathrm{AEP}_{\text {grain }}$ in year 2 in contrasts to

364 that in year 1.

365 The $\mathrm{P}$ balance (Figure 2) was significantly affected by both $\mathrm{P}$ and water management. Reduced irrigation 366 consistently decreased the $\mathrm{P}$ balance. Without $\mathrm{P}$ application (NoP $=\mathrm{P} 0$ ) the $\mathrm{P}$ balance was smallest and

367 negative, while the balance was largest and moderately positive (ca. $3.6 \mathrm{~kg} \mathrm{ha}^{-1}$ ) for MicroP2 and

368 MicroP3.

\section{Pot experiment}

\section{Shoot development}

372 All P application methods enhanced the plant development at early stage of the crop compared to the 373 control, but an extra benefit from optimal broadcasting became clear around 28 DAS in tiller number.

374 With MicroP, plants developed relatively similar as for SubP, however, the $\mathrm{P}$ rate in the latter treatment 375 was much larger (ca. 4 fold). (Figure 4)

376 For shoot mass, three similar clusters were observed coinciding with the $\mathrm{P}$ treatments. MicroP yielded

377 similar biomass than obtained under SubP, despite larger soil P dose in the latter than in the placement, 378 both being significantly larger than NoP and smaller than PlusP. DP significantly reduced biomass under 379 MicroP and PlusP, while it enhanced biomass production under SubP. (Table 5) 


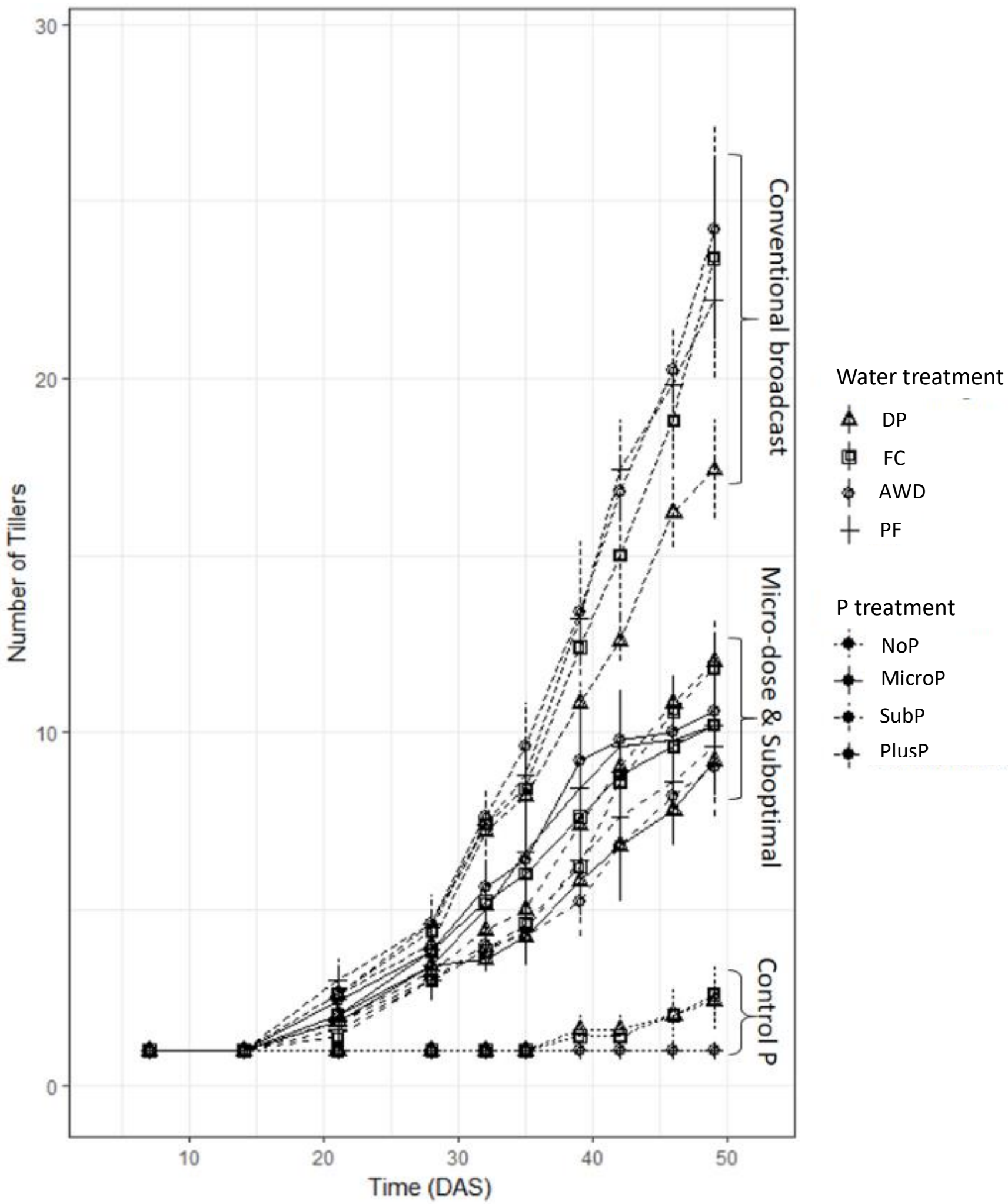

Figure 4: Plant development (tillers) of lowland rice grown in pots with $P$ deficient lowland soil treated with combinations of water management techniques (Drying periods (DP), field capacity (FC), alternate wetting and drying (AWD), and Permanent Flooding (PF)) and P management options (No P application (NoP), micro-dose placement (MicroP), suboptimal broadcasting (SubP), and conventional broadcasting (PlusP)). For both the number of leaves and tillers at 49 DAS, the interaction between $P$ and water management was significant $(P<0.001)$ in the ANOVA 


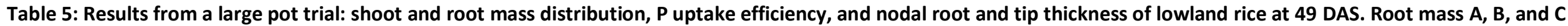

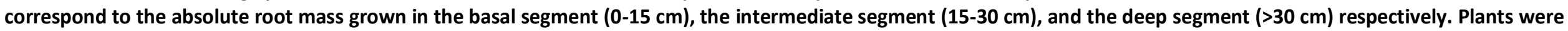

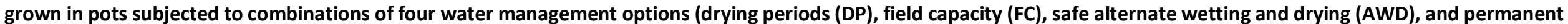

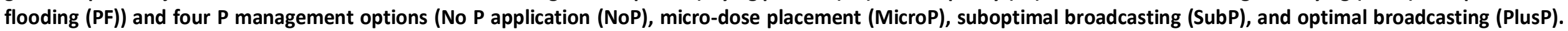
Data are presented as means with (standard errors).

\begin{tabular}{|c|c|c|c|c|c|c|c|c|}
\hline $\mathbf{P}$ & Water & $\begin{array}{l}\text { Shoot } \\
\text { mass }\end{array}$ & $\begin{array}{l}\text { Root mass } \\
\text { A }\end{array}$ & $\begin{array}{l}\text { Root mass } \\
\text { B }\end{array}$ & $\begin{array}{l}\text { Root mass } \\
\mathrm{C}\end{array}$ & Pup root & Pup $_{\text {nodal }}$ & $\begin{array}{l}\text { Nodal } \\
\text { thickness }\end{array}$ \\
\hline & & [g] & [g] & [g] & [mg] & {$\left[\mathrm{mg} \mathrm{g}^{-1}\right]$} & [ $\mu$ g nodal $^{-1}$ ] & {$[\mathrm{mm}]$} \\
\hline \multirow{4}{*}{ NoP } & DP & $0.95(0.12)$ & $0.12(0.05)$ & $0.05(0.02)$ & $38(14)$ & $5.2(0.6)$ & $113(21)$ & $0.64(0.18)$ \\
\hline & FC & $0.85(0.13)$ & $0.21(0.03)$ & $0.06(0.01)$ & $20(2)$ & $3.2(0.2)$ & $31(3)$ & $0.93(0.01)$ \\
\hline & AWD & $0.28(0.02)$ & $0.07(0.01)$ & $0.04(0.01)$ & $4(2)$ & $1.6(0.2)$ & $7(1)$ & $0.60(0.03)$ \\
\hline & PF & $0.32(0.05)$ & $0.12(0.02)$ & $0.04(0.01)$ & $6(4)$ & $1.1(0.1)$ & $8(1)$ & $0.56(0.05)$ \\
\hline \multirow{4}{*}{ MicroP } & DP & $6.90(0.75)$ & $1.50(0.28)$ & $0.64(0.10)$ & $440(160)$ & $2.5(0.2)$ & $68(5)$ & $1.29(0.04)$ \\
\hline & FC & $8.98(0.68)$ & $2.15(0.15)$ & $0.71(0.07)$ & $284(66)$ & $2.2(0.2)$ & $44(4)$ & $1.30(0.02)$ \\
\hline & AWD & $9.97(1.39)$ & $3.09(0.30)$ & $0.58(0.05)$ & $135(20)$ & $1.9(0.3)$ & $34(5)$ & $1.59(0.10)$ \\
\hline & PF & $9.57(1.28)$ & $2.76(0.38)$ & $0.49(0.16)$ & $82(38)$ & $1.9(0.2)$ & $28(2)$ & $1.42(0.05)$ \\
\hline \multirow{4}{*}{ SubP } & DP & $9.34(0.47)$ & $1.75(0.19)$ & $0.76(0.08)$ & $497(23)$ & $3.6(0.4)$ & $124(9)$ & $1.08(0.09)$ \\
\hline & FC & $9.22(0.65)$ & $2.18(0.10)$ & $0.57(0.08)$ & $196(23)$ & $3.1(0.2)$ & $65(3)$ & $1.18(0.12)$ \\
\hline & AWD & $7.45(0.73)$ & $2.27(0.11)$ & $0.31(0.05)$ & $56(12)$ & $2.7(0.4)$ & $43(4)$ & $1.68(0.06)$ \\
\hline & PF & $7.82(0.47)$ & $2.15(0.20)$ & $0.33(0.06)$ & $55(21)$ & $2.6(0.4)$ & $38(3)$ & $1.56(0.05)$ \\
\hline \multirow{7}{*}{ PlusP } & DP & $15.38(0.54)$ & $2.57(0.18)$ & $0.78(0.07)$ & $366(83)$ & $4.6(0.3)$ & $140(7)$ & $1.22(0.11)$ \\
\hline & FC & $20.40(1.00)$ & $4.86(0.28)$ & $0.98(0.07)$ & $220(29)$ & $3.8(0.5)$ & $104(11)$ & $1.48(0.06)$ \\
\hline & AWD & $21.98(1.42)$ & $4.93(0.37)$ & $1.33(0.18)$ & $260(67)$ & $3.6(0.3)$ & $80(8)$ & $1.72(0.04)$ \\
\hline & PF & $21.67(0.99)$ & $4.62(0.36)$ & $0.63(0.10)$ & $84(21)$ & $3.4(0.1)$ & $75(3)$ & $1.86(0.05)$ \\
\hline & Water & "** & "*** & "** & "*** & "*** & "*** & **** \\
\hline & $\mathbf{P}$ & $* * *$ & $* * *$ & $* * *$ & $* * *$ & $* * *$ & $* * *$ & $* * *$ \\
\hline & Water $\times \mathbf{P}$ & $* * *$ & $* * *$ & $* * *$ & $* *$ & $* * *$ & $* * *$ & $* * *$ \\
\hline
\end{tabular}


392 Three similar clusters as for shoot biomass were observed for total root mass, this was significantly 393 reduced with DP only for PlusP (Table S4, Supplementary Information). The absolute root biomass found 394 in each layer is presented in Table 5. The root biomass in the deepest layer $(>30 \mathrm{~cm})$ strongly increased 395 with reduced water availability (DP $>$ FC $>$ AWD $>$ PF). Under soil submergence there were no significant 396 differences between the P treatments, while deep root biomass under AWD increased for PlusP. Within 397 DP and FC, deep root biomass was decreased without P application.

398 Figure 5 shows how the relative root biomass increases towards deeper layers when less water is applied.

399 The mass fraction consistently decreased in the basal part while it increased in deepest layers. The 400 response was relatively similar for each $\mathrm{P}$ treatment and strongest allocation shifts were observed under 401 DP followed by FC.

402 Nodal thickness generally increased with P application. Without P application, nodal thickness was largest 403 under FC, while this decreased with decreasing water application (FC and DP) when P was applied. (Table 404 5)

405 Lateral root density at the nodal root base was consistently highest under PF, and lowest under DP (Figure 406 S2, Supplementary Information). In contrast, the lateral root density for the deepest roots consistently 407 increased under FC and DP. P application did not affect the lateral root density at the root base, and the 408 deep roots, but an inconsistent $\mathrm{P} \times$ water interaction was observed for the intermediate roots. (Figure S2)

409 Lateral root thickness at the root base generally increased with decreased water application (DP and FC) 410 but a difference between AWD and FC was only observed for NoP and MicroP. Lateral root thickness was 411 significantly largest under DP with MicroP. The lateral root thickness in the intermediate and deep roots 412 increased with decreased water application and this lateral root thickness similarly increased with any 413 method of P application compared to the control. (Figure S2) 


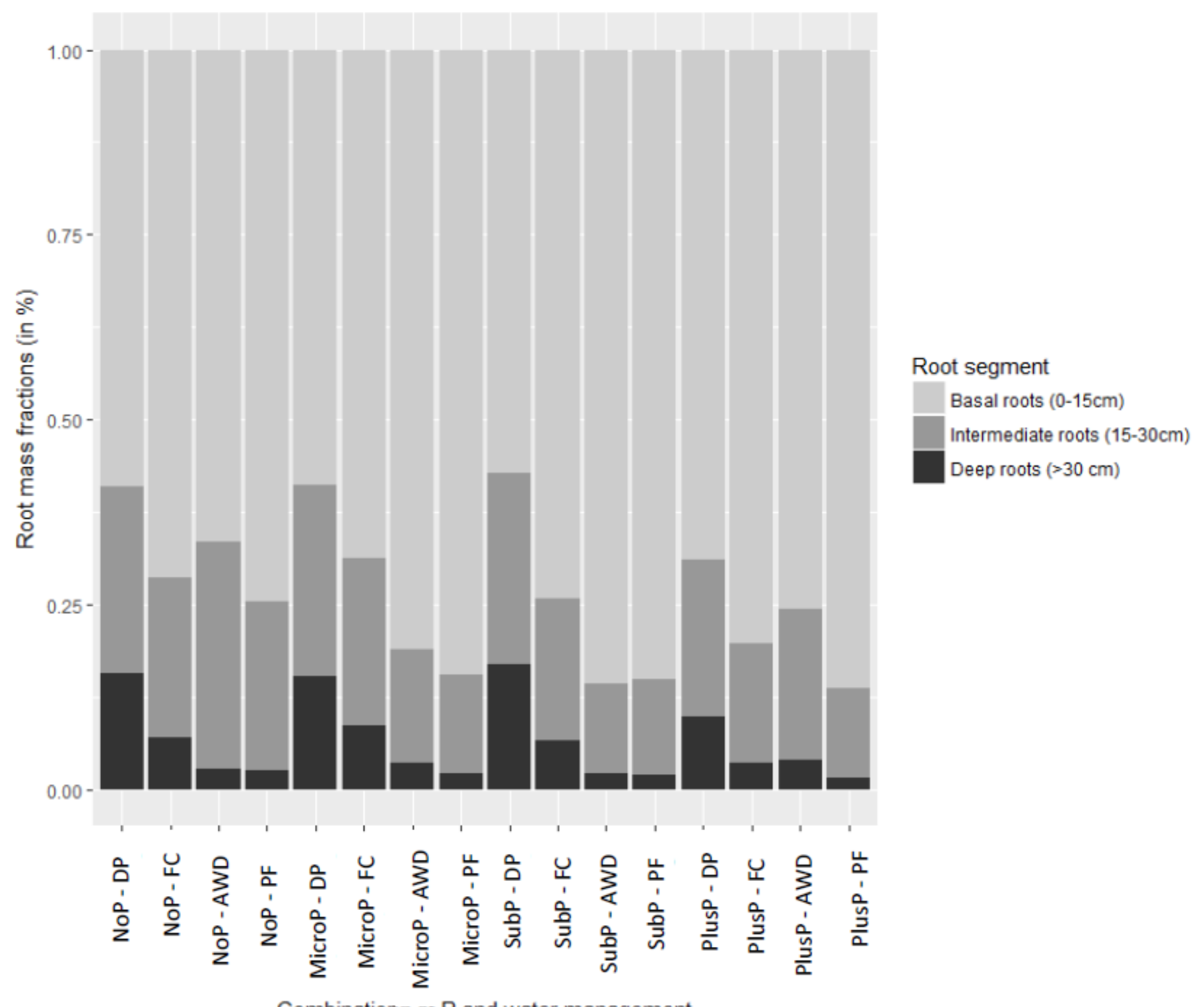

Combinations or $\mathrm{P}$ and water management

Figure 5: The root mass distribution of rice in the soil. Fractions of the total root mass are presented for each segment of soil depth (basal roots $(0-15 \mathrm{~cm})$, intermediate roots $(15-30 \mathrm{~cm})$, deep roots $(>30 \mathrm{~cm}))$. Plants were grown in pots with $P$ deficient lowland soil subjected to combinations of water management techniques (Drying periods (DP), field capacity (FC), alternate wetting and drying (AWD), and soil submergence (PF)) and P management options (No P application (NoP), micro-dose placement (MicroP), suboptimal broadcasting (SubP), and conventional broadcasting (PlusP)). 
415 Secondary branching degree at the nodal root base and at the intermediate segment generally increased

416 with decreasing water application, but this trend was not observed without $\mathrm{P}$ application. For the deepest

417 roots, this secondary branching degree showed a similar increasing trend with decreased water

418 application. Under DP and FC, secondary branching degree at the nodal root base decreased under MicroP

419 compared to SubP and PlusP. In contrast, this secondary branching degree at the deepest roots increased

420 under MicroP compared to SubP under FC. (Figure S2)

421 Soil P concentrations

422 The $\mathrm{P}$ concentration in the soil solution ranged $<0.03$ (detection limit) $-0.39 \mathrm{mg} \mathrm{P} \mathrm{L}^{-1}$ and was significantly

423 affected by the P treatments, not by water management. The SubP and PlusP consistently and significantly

424 increased the P concentrations in the soil solution, while corresponding concentrations for the control 425 and the P placement were both below detection limit (data not shown).

426 P uptake, acquisition efficiency, and fertilizer use efficiency

427 Total P uptake at 49 DAS can be grouped into three clusters ( NoP $<$ MicroP SubP $<$ PlusP), and reduced 428 water use under SubP significantly increased total $P$ uptake (DP $>$ FC $>$ AWD $>P F)$, while DP reduced $P$ uptake 429 under PlusP. (Table S4, Supplementary Information)

430 The Pup root was consistently smaller for MicroP compared to PlusP, with the SubP treatment in between.

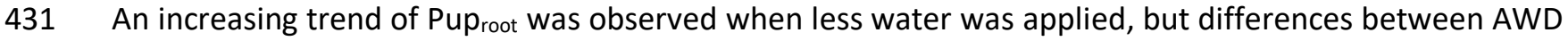
432 and PF were never significant. The difference between FC and AWD (\& PF) was only significant without P 433 application (Table 5).

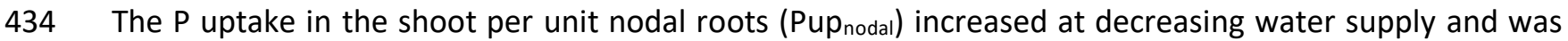
435 larger under FC than at higher water supply, a trend repeating the field observation. (Table 5) 
436 The AEP 49DAS was consistently largest for MicroP, exceeding the other treatments with a factor of ca. 4.

437 For MicroP, the AEP $49 \mathrm{DAs}$ decreased by DP, while water management had no such significant effects under

438 SubP and PlusP. With reduced irrigation (i.e. FC and DP), the AEP 49DAs was larger under SubP compared to 439 PlusP. (Table S4, Supplementary Information)

$441 \quad$ Modeling $\mathbf{P}$ diffusion, adsorption and plant availability of placed $\mathbf{P}$ under different water regimes

442 The modelled diffusion from the placed P fertilizer over time is given in Figure 6. Increased water content

443 of the soil, increases the P diffusion, thereby leading to smaller P concentrations in solution because more

444 sorption sites are reached and, consequently, contributing to a larger amount of $\mathrm{P}$ that is finally adsorbed 445 (Figure 6).

446 With larger placements rates, smaller fractions of P (in \%) will be adsorbed because a larger proportion of 447 the binding sites are saturated. Soil saturation at the lowest dose of $\mathrm{P}$ yields highest immobilization of 448 added P (Figure 6). 
$12 \mathrm{mg}$ P - Field Capacity

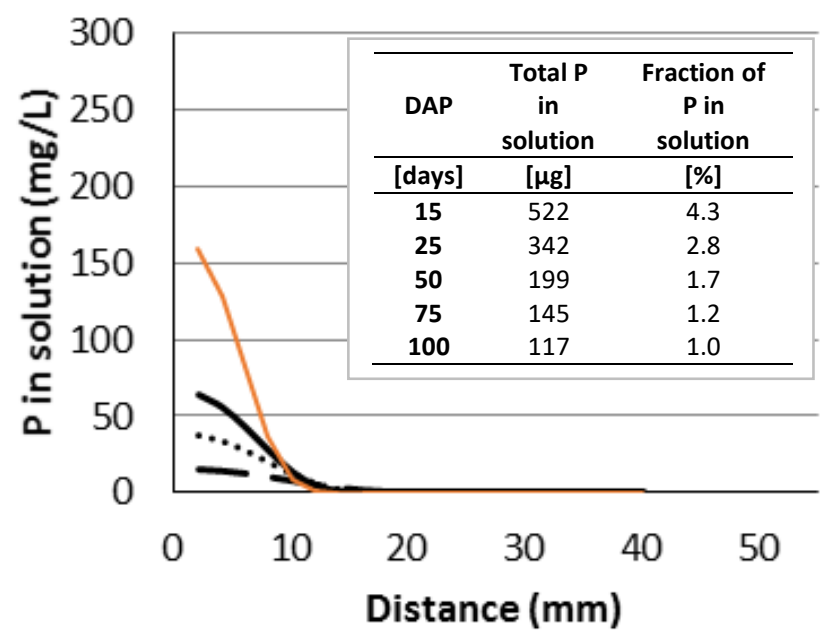

24 mg P - Field Capacity

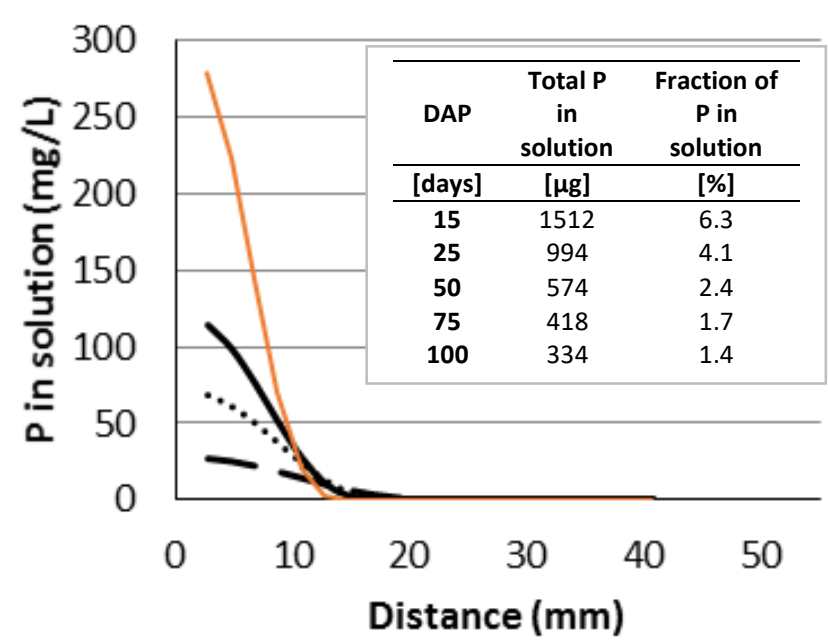

12 mg P - Saturation

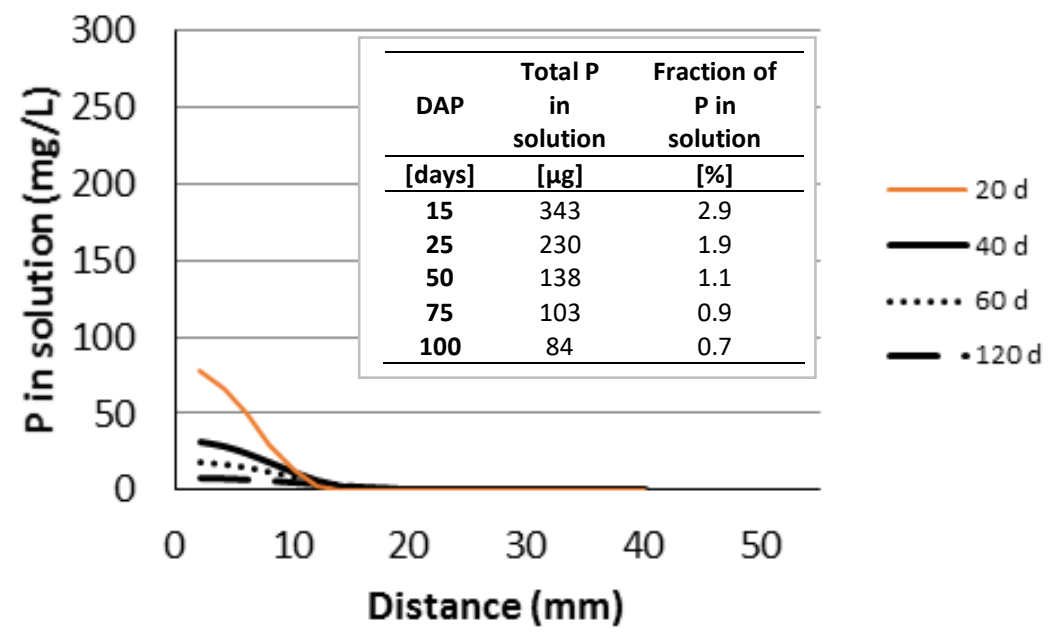

24 mg P - Saturation

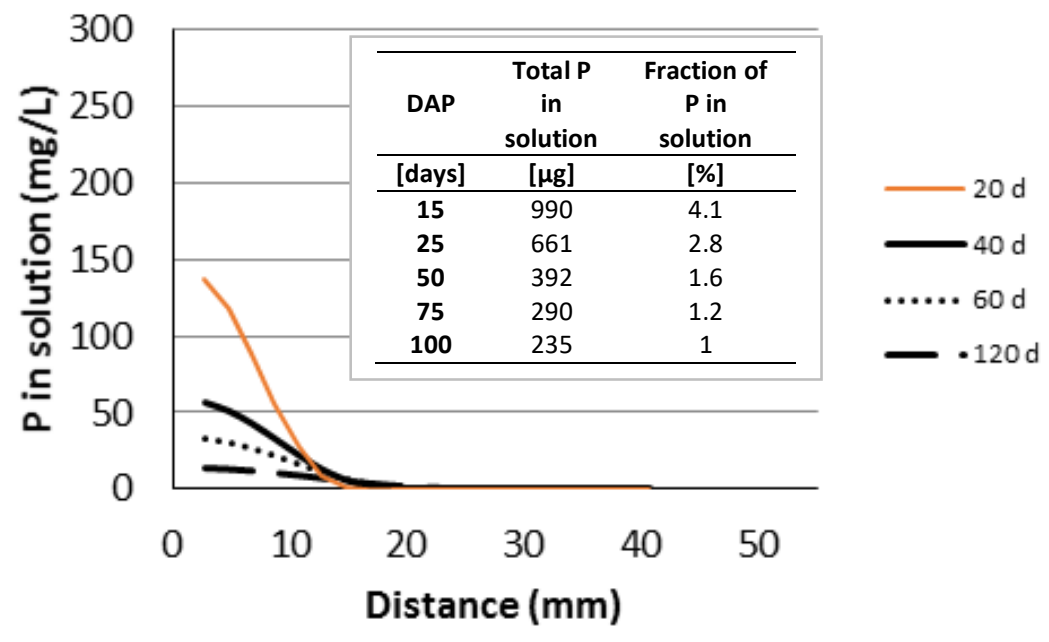

Figure 6: The modeled $P$ concentration in soil solution $\left(\mathrm{mg} \mathrm{L}^{-1}\right)$ over the distance from the application point $(\mathrm{mm})$ at $20,40,60$, and 120 days after placement (DAP). Calculations were done for two placement rates (12 vs. $24 \mathrm{mg}$ P) and two water regimes (field capacity (pF $=2$ ) and soil submergence $(\mathrm{pF}=0))$. Modeled total available $P$ in solution $(\mu \mathrm{g})$ integrated over the distance to the application point at $15,25,50,75$, and 100 days after placement (DAP) and the adsorbed fraction from the placed $P(\%)$ are presented in the tables. These variables can be used as estimators for the plant available $P$ from P placements under contrasting water management. 


\section{Combined effects of phosphorus and water supply on rice development, $P$ uptake, and grain yield}

452 This study confirmed that $\mathrm{P}$ management has a major effect on rice establishment and grain yield in $\mathrm{P}$ 453 deficient lowlands. While in our study effects of water management were subordinate to P effects, 454 interactions between P and water management should definitely be considered. Contrasting responses 455 to reduced irrigation (i.e. field capacity and alternate wetting and drying) versus permanently flooded 456 conditions on rice yields have previously been reported in literature (Yang et al., 2007; Chu et al., 2015;

457 Dodd et al., 2015), but it remains important to understand the mechanisms explaining why yields and 458 yield attributing characteristics of FC, AWD, and PF vary under different conditions.

459 In this study, drying periods reduced growth when $\mathrm{P}$ was sufficiently available, while it enhanced growth under P limitations. In addition, a beneficial effect of FC (compared to flooding) was generally observed 461 when P limited growth, while no such water effect occurred when larger doses of P were applied. These 462 observations are in contrast with the general assumption that $\mathrm{P}$ is released under anaerobic conditions 463 (Kirk et al., 1990). After an initial P release upon flooding, $P$ availability may indeed drop again in P deficient 464 soils due to resorption of $\mathrm{P}$ on clays/metal oxyhydroxydes or due to precipitation of Fe(II)-P compounds 465 (Amery and Smolders, 2012; Smolders et al., 2017). Enhanced growth and yield in response to reduced water application under P limitations, would follow from multiple co-occurring processes. Firstly, the

467 presence of toxic compounds $\left(\mathrm{Fe}^{2+}, \mathrm{H}_{2} \mathrm{~S}\right)$ in the soil under anaerobic conditions can inhibit root respiration 468 and therefore affect growth (Ramasamy et al., 1997). Due to the interaction of $P$ and Fe in soils, it is 469 suggested that effects of Fe toxicity would be more severe when $\mathrm{P}$ is deficient as the alleviating capacity 470 of roots is reduced when P is limiting (Becker and Asch, 2005; Das et al., 2017; Sahrawat, 2005). Secondly,

471 beneficial interactions with mycorrhizae would be inhibited under soil submergence, but not under field 472 capacity (Chen et al., 2017). Thirdly, rooting patterns (in terms of structure and distribution) can be 
473 affected under different water treatments and this would influence growth and nutrient acquisition (De

474 Bauw et al., 2019; Yang et al., 2012; Zhang et al., 2009), as assessed in the following section. Finally, as 475 shown by the diffusion model used in this study (Figure 6), reduced $\mathrm{P}$ diffusion and reduced $\mathrm{P}$ sorption of 476 small localized $\mathrm{P}$ placements additionally enhance the $\mathrm{P}$ uptake and rice growth under field capacity in 477 comparison with alternate wetting and drying or soil submergence.

478 Micro-dose placement enhanced rice development and grain yield and there were no differences 479 between rates of 3.45 and $6.90 \mathrm{~kg} \mathrm{P} \mathrm{ha}^{-1}$ under field capacity, which was also observed by Vandamme et 480 al. (2018). The likelihood for P precipitation increases at a higher application rate and could explain why there are no growth differences between the different rates, while P is still deficient (Sánchez, 2019).

482 Under saturation, it was shown that enhanced $\mathrm{P}$ diffusion increases $\mathrm{P}$ sorption, which thus reduces the 483 final $\mathrm{P}$ availability of a P micro-dose placement for rice production.

P application strongly reduces the time to maturity, which was also observed for micro-dose placements 485 486 by Vandamme et al. (2018). Placing such small doses of $P$ fertilizers can thus reduce the length of the cropping season which not only reduces risk of pests and diseases, but it can also be used as a technique 487 to escape terminal droughts (Fukai et al., 1998; Price et al., 2002).

\section{Root development, root architecture and relations with stress resilience}

490 The promotion of root development in response to various soil conditions can be considered as a type of 491 phenotypic plasticity, in which a plant alters its phenotype in response to changing environmental 492 conditions (Gowda et al., 2011; Huang, 2006; Kano et al., 2011). Previously, Barison and Uphoff (2011) 493 have shown a superior rice root functioning and an enhanced nutrient uptake under reduced irrigation. 494 Under P deficiency, beneficial effects of root modifications due to reduced water availability were 495 observed for rice by De Bauw et al. (2019) and it was hypothesized that such plastic root traits could 
successfully be exploited to enhance $\mathrm{P}$ uptake by altering soil and water management rather than targeting such plastic root traits in breeding only.

This work clearly confirms that the root development of lowland rice can indeed be manipulated by altering water management through modifying root architecture and biomass allocation and, to a minor extent, also by $\mathrm{P}$ management by enhancing root biomass production. For lowland rice, typically around 60 to $80 \%$ of the root biomass is located in the upper $15 \mathrm{~cm}$ of the soil, which entails a strong drought sensitivity (Kano-Nakata et al., 2013). Rice roots under flooding and AWD have previously been observed to reach depths of 49 and $78 \mathrm{~cm}$, respectively, but only 7 to $15 \%$ of the roots exist at depths below $30 \mathrm{~cm}$

504 (Kato et al., 2013; Wade et al., 1998; Yoshida, 1981). Reduced irrigation (DP and FC) strongly increased 505 the fractions of root biomass (in \%) in the deepest layer. While the fractions of root biomass in each layer 506 were relatively similar for each P treatment, the differences in absolute root mass in each layer were huge, 507 depending on $\mathrm{P}$ application. Root mass in deep layers can thus be enhanced by $\mathrm{P}$ application, but to what extent the maximum depth, the deep root fraction, or the absolute biomass in deep layers is important

509 for drought avoidance has to be further examined and this probably depends on the root morphology and 510 the distribution and fluctuations of the available water (Gowda et al., 2011).

511 The general structure of the rice root system is illustrated in Figure S2, which was also described by Kono 512 et al. (1972); Yamauchi et al. (1987); and Nestler et al. (2016). The nodal root base is characterized by 513 highly dense S-type roots (i.e. thin unbranched roots), and lateral root density gradually reduces when 514 going to deeper layers. With increasing depth, thicker laterals with higher order branches (M- and L-type 515 roots) are formed. It is now shown that lateral root density and secondary branching in the deeper layers 516 increase with reduced water application, even when there is no water deficit. Several studies have 517 demonstrated increased root length density at depth to be associated with greater water extraction from 518 deep soil (Henry, 2013; Lilley and Fukai, 1994; Okada et al., 2002; Wade et al., 1999) and the stronger 519 developed vascular system in deep M- and L-type laterals highlight their important role for drought 
521 at deeper layers by reduced irrigation, while not imposing a deficit, thus contributes to drought avoidance

522 and enhanced resilience under potential drought events during later stages of the growth cycle (Fukai and

523 Cooper, 1995; Gowda et al., 2011).

524 In this study, lateral root density at the nodal base (S-type roots) decreased with reduced water 525 application, while such a response was not observed by De Bauw et al. (2019). However, such a reduced 526 basal lateral root density was previously observed to increase the drought tolerance in maize (Zhan et al., 527 2015), and for rice this was observed in response to aerobic conditions by Kato et al. (2013). Interestingly, 528 the observed responses of the basal lateral root density to water management are much smaller than the 529 genotypic variations observed by De Bauw et al. (2019), and when this basal lateral density is desired to 530 be modified (in order to enhance drought tolerance or P uptake efficiency), thoughtful genotype selection 531 would still be more effective than altering water management only.

532 P uptake efficiency consistently increased with reduced irrigation, especially when P was limiting. As P 533 availability in the rhizosphere solution was not altered by the water treatments and P diffusion generally 534 reduces with reduced water availability (Drew and Nye, 1970), it is indeed suggested that root 535 modifications (i.e. reduced nodal thickness and increased secondary root branching) must be responsible 536 for such an enhanced P uptake efficiency under reduced water application, as also observed by De Bauw 537 et al. (2019). Such beneficial effects of root responses would be strongest when a suboptimal P 538 concentration is more homogeneously distributed through the soil, but when $\mathrm{P}$ is placed in less deficient 539 soils, both processes (diffusion \& sorption, and root modifications) will contribute to enhanced P uptake 540 under field capacity.

541 Contrary to our expectations, we did not observe strong effects of the type of $\mathrm{P}$ application on the root 542 morphology of rice (i.e. root proliferation or cluster roots). Dense rooting "patches" in response to 
543 localized P application were however previously observed by He et al. (2003); and Hodge (2004) and it 544 should be further examined under which conditions such micro-dose placements affect the root 545 architecture of rice.

549 Our results indicate the opportunity in strategic combinations of $\mathrm{P}$ and water management, depending on 550 site characteristics and resources of the farmer. Obviously, broadcasting a large amount of P fertilizer

551 remains advisable when $\mathrm{P}$ is strongly deficient, but in reality resource limitations often preclude such large 552 P applications (Nziguheba et al., 2016). Yield gaps between conventional broadcasts and micro-dose 553 placements are however expected to become smaller when P stress is less severe. The agronomic fertilizer 554 use efficiencies obtained with micro-dosing were substantially larger than those under conventional 555 broadcasting and much larger than commonly observed values below $120 \mathrm{~kg}_{\text {grain }} \mathrm{kg}^{-1} \mathrm{P}$ for rice 556 (Dobermann et al., 1998; Fageria et al., 2011). Micro-dose placements therefore lead to a much better 557 return on investment, especially when applying small rates. Given the prevalence of P deficiency in many 558 lowlands of SSA (Margenot et al., 2016), placing micro-doses of P fertilizer may thus be an economically 559 viable strategy for resource-poor farmers to increase rice yields (Vandamme et al., 2018).

560 Importantly, small P placement rates (i.e. $3.45 \mathrm{~kg} \mathrm{ha}^{-1}$ ) resulted in a slightly positive P-balance close to 561 zero, and care should be taken to not further deplete the soil P reserves when this balance of the soil 562 turns negative. In contrast, a placement rate of $6.9 \mathrm{~kg} \mathrm{ha}^{-1}$ resulted in a fairly positive balance, which 563 highlights the potential of this method for resource poor farmers to reverse the declining P-trends in 564 deficient soils. Additionally, placements can reduce the risk of runoff and nutrient losses (Kapoor et al., 565 2008), especially under flooding (Zhan et al., 2014). Therefore, we suggest that P micro-dose placements 
combined with additive, supportive broadcasts adjusted to the requirements can form a sustainable

567 method to maintain the $\mathrm{P}$ balance in equilibrium (after overcoming $\mathrm{P}$ deficiency), while enhancing

568 fertilizer efficiency and recovery rates. The application of micro-dose placements generally requires more

569 labor when manually done (Aune et al., 2007), but opportunities for further mechanization towards

570 precision agriculture do exist (Bautista et al. 2001).

571 In lowlands with P limitations, maintaining the field at field capacity benefits $\mathrm{P}$ uptake and yield versus

572 permanent flooding. Negative effects of field capacity versus permanent flooding on P uptake were only

573 observed in soils with a coarse texture (Kato et al., 2016; Seng et al., 1998) and attention should thus be

574 paid in such situations. Without $\mathrm{P}$ application or when placing $\mathrm{P}$ at small rates, farmers should reduce

575 irrigation to increase outputs in P-deficient lowlands, while the choice of water management would

576 become less important when applying larger rates of $\mathrm{P}$ fertilizer.

577 Besides enhancing root morphology and root resilience, reduced irrigation implies a more sustainable and

578 efficient water use (Bouman et al., 2005; de Vries et al., 2010; Matsuo and Mochizuki, 2009; Shaibu et al., 579 2015). While keeping the field at field capacity weed management requires more attention (Akobundu 1987; Zhao et al. 2007; de Vries et al. 2010). With this perspective, further research should examine to 581 what extent normal AWD (or safe AWD under fast drying conditions) can also improve root functioning 582 (Kano-Nakata et al., 2013; Kato et al., 2013), P uptake, and yield under P limitations (as observed for field 583 capacity compared to soil submergence), while maintaining the advantage of suppressing weeds.

\section{Conclusions}

586 We demonstrate that root development of rice largely responds to water management. Under $\mathrm{P}$ 587 deficiency and at small placed $\mathrm{P}$ doses, reduced irrigation enhances rice development, $\mathrm{P}$ uptake, and yield. 588 We argue that P micro-dose placements in combination with a moderate water supply could be an 
589 efficient entry point to intensify rice production and to reverse the declining trend in $\mathrm{P}$ reserves in 590 deficient lowlands.

\section{Conflict of interest}

593 The authors have no conflict of interest.

\section{$595 \quad$ Acknowledgements}

596 This study was conducted at the Africa Rice Center in Tanzania and partly financed through the project

597 "East African Wetlands: Optimizing sustainable production for future food security (WETLANDS)" funded

598 by the German Federal Ministry for Economic Cooperation and Development, commissioned by the 599 Deutsche Gesellschaft für Internationale Zusammenarbeit. Lab work was partly conducted at the KU 600 Leuven in Belgium and the work was additionally supported by the Belgian VLIR-UOS through a scholarship 601 (VLADOC grant). We thank Nassoro Hemedi for the maintenance of the trials. We are grateful to Karlien 602 Cassaert for the administrative support and we thank Dr. Baanda for the hospitality at the Sokoine 603 University of Agriculture. 


\section{$\underline{\text { References }}$}

Akobundu, I.O., 1987. Weed science in the tropics. J. Wiley.

Amery, F., Smolders, E., 2012. Unlocking fixed soil phosphorus upon waterlogging can be promoted by increasing soil cation exchange capacity. Eur. J. Soil Sci. 63, 831-838. doi:10.1111/j.1365-2389.2012.01478.x

Andriamananjara, A., Rakotoson, T., Razanakoto, O.R., Razafimanantsoa, M.-P., Rabeharisoa, L., Smolders, E., 2018. Farmyard manure application in weathered upland soils of Madagascar sharply increase phosphate fertilizer use efficiency for upland rice. F. Crop. Res. 222, 94-100. doi:10.1016/j.fcr.2018.03.022

Aune, J.B., Bationo, A., 2008. Agricultural intensification in the Sahel - The ladder approach. Agric. Syst. 98, 119125. doi:10.1016/J.AGSY.2008.05.002

Aune, J.B., Doumbia, M., Berthe, A., 2007. Microfertilizing Sorghum and Pearl Millet in Mali. Outlook Agric. 36, 199-203. doi:10.5367/000000007781891504

Bagayoko, M., Maman, N., Pale, S., Sirifi, S., Taonda, S.J.B., Traore, S., Mason, S.C., 2011. Microdose and N and P fertilizer application rates for pearl millet in West Africa. African J. Agric. Res. 6, 1141-1150. doi:10.5897/ajar10.711

Bañoc, D.M., Yamauchi, A., Kamoshita, A., Wade, L.J., Pardales, J.R., 2000. Genotypic Variations in Response of Lateral Root Development to Fluctuating Soil Moisture in Rice. Plant Prod. Sci. 3, 335-343. doi:10.1626/pps.3.335

Barison, J., Uphoff, N., 2011. Rice yield and its relation to root growth and nutrient-use efficiency under SRI and conventional cultivation: an evaluation in Madagascar. Paddy Water Environ. 9, 65-78. doi:10.1007/s10333010-0229-z

Bautista, E.U., Koike, M., Suministrado, D.C., 2001. PM-Power and Machinery: Mechanical Deep Placement of Nitrogen in Wetland Rice. J. Agric. Eng. Res. 78, 333-346. doi:10.1006/JAER.2000.0675

Bayan, H.C., Lourduraj, A.C., 2000. Phosphorus management in rice and rice based cropping systems - A review. Agric. Rev 21, 89-96.

Becker, M., Asch, F., 2005. Iron toxicity in rice-conditions and management concepts. J. Plant Nutr. Soil Sci. 168, 558-573. doi:10.1002/jpln.200520504

Becker, M., Johnson, D.E., Wopereis, M.C.S., Sow, A., 2003. Rice yield gaps in irrigated systems along an agroecological gradient in West Africa. J. Plant Nutr. Soil Sci. 166, 61-67. doi:10.1002/jpln.200390013

Bielders, C.L., Gérard, B., 2015. Millet response to microdose fertilization in south-western Niger: Effect of antecedent fertility management and environmental factors. F. Crop. Res. 171, 165-175. doi:10.1016/J.FCR.2014.10.008

Bouman, B.A.M., Humphreys, E., Tuong, T.P., Barker, R., 2007. Rice and Water. Adv. Agron. 92, 187-237. doi:10.1016/S0065-2113(04)92004-4

Bouman, B.A.M., Peng, S., Castañeda, A.R., Visperas, R.M., 2005. Yield and water use of irrigated tropical aerobic rice systems. Agric. Water Manag. 74, 87-105. doi:10.1016/J.AGWAT.2004.11.007

Camara, B.S., Camara, F., Berthe, A., Oswald, A., 2013. International journal of agriscience, International Journal of AgriScience. International Academic Journals Pub.

Carrijo, D.R., Lundy, M.E., Linquist, B.A., 2017. Rice yields and water use under alternate wetting and drying irrigation: A meta-analysis. F. Crop. Res. 203, 173-180. doi:10.1016/J.FCR.2016.12.002

Chen, X.-W., Wu, F.-Y., Li, H., Chan, W.-F., Wu, S.-C., Wong, M.-H., 2017. Mycorrhizal colonization status of lowland rice (Oryza sativa L.) in the southeastern region of China. Environ. Sci. Pollut. Res. 24, 5268-5276. 
doi:10.1007/s11356-016-8287-4

Chu, G., Wang, Z., Zhang, H., Liu, L., Yang, J., Zhang, J., 2015. Alternate wetting and moderate drying increases rice yield and reduces methane emission in paddy field with wheat straw residue incorporation. Food Energy Secur. 4, 238-254. doi:10.1002/fes3.66

Das, S., Tyagi, W., Rai, M., Yumnam, J.S., 2017. Understanding Fe ${ }^{2+}$ toxicity and P deficiency tolerance in rice for enhancing productivity under acidic soils. Biotechnol. Genet. Eng. Rev. 33, 97-117. doi:10.1080/02648725.2017.1370888

De Bauw, P., Vandamme, E., Lupembe, A., Mwakasege, L., Senthilkumar, K., Merckx, R., 2019. Architectural Root Responses of Rice to Reduced Water Availability Can Overcome Phosphorus Stress. Agronomy 9, 11. doi:10.3390/agronomy9010011

de Vries, M.E., Rodenburg, J., Bado, B. V., Sow, A., Leffelaar, P.A., Giller, K.E., 2010. Rice production with less irrigation water is possible in a Sahelian environment. F. Crop. Res. 116, 154-164. doi:10.1016/J.FCR.2009.12.006

Degryse, F., McLaughlin, M.J., 2014. Phosphorus Diffusion from Fertilizer: Visualization, Chemical Measurements, and Modeling. Soil Sci. Soc. Am. J. 78, 832. doi:10.2136/sssaj2013.07.0293

Dobermann, A., Cassman, K.G., Mamaril, C.P., Sheehy, J.E., 1998. Management of phosphorus, potassium, and sulfur in intensive, irrigated lowland rice. F. Crop. Res. 56, 113-138. doi:10.1016/S0378-4290(97)00124-X

Dodd, I.C., Puértolas, J., Huber, K., Pérez-Pérez, J.G., Wright, H.R., Blackwell, M.S.A., 2015. The importance of soil drying and re-wetting in crop phytohormonal and nutritional responses to deficit irrigation. J. Exp. Bot. 66, 2239-52. doi:10.1093/jxb/eru532

Drew, M.C., Nye, P.H., 1970. The supply of nutrient ions by diffusion to plant roots in soil. Plant Soil 33, 545-563. doi:10.1007/BF01378245

Fageria, N.K., Santos, A.B., Heinemann, A.B., 2011. Lowland rice genotypes evaluation for phosphorus use efficiency in tropical lowland. J. Plant Nutr. 34, 1087-1095. doi:10.1080/01904167.2011.558153

FAOSTAT, 2018. FAOSTAT [WWW Document]. URL http://www.fao.org/faostat/en/\#home (accessed 3.23.18).

Fukai, S., Cooper, M., 1995. Development of drought-resistant cultivars using physiomorphological traits in rice. F. Crop. Res. 40, 67-86. doi:10.1016/0378-4290(94)00096-U

Fukai, S., Sittisuang, P., Chanphengsay, M., 1998. Increasing Production of Rainfed Lowland Rice in Drought Prone Environments. Plant Prod. Sci. 1, 75-82. doi:10.1626/pps.1.75

Garrity, D.P., Mamaril, C.P., Soepardi, G., 1990. Phosphorus requirements and management in upland rice-based cropping systems., in: Phosphorus Requirements for Sustainable Agriculture in Asia and Oceania. Proceedings of a Symposium, 6-10 March 1989. International Rice Research Institute, pp. 333-347.

Gowda, V.R.P., Henry, A., Yamauchi, A., Shashidhar, H.E., Serraj, R., 2011. Root biology and genetic improvement for drought avoidance in rice. F. Crop. Res. 122, 1-13. doi:10.1016/J.FCR.2011.03.001

He, Y., Liao, H., Yan, X., 2003. Localized supply of phosphorus induces root morphological and architectural changes of rice in split and stratified soil cultures. Plant Soil 248, 247-256. doi:10.1023/A:1022351203545

Henry, A., 2013. IRRI's drought stress research in rice with emphasis on roots: accomplishments over the last 50 years. Plant Root 7, 92-106. doi:10.3117/plantroot.7.92

Hodge, A., 2004. The plastic plant: root responses to heterogeneous supplies of nutrients. New Phytol. 162, 9-24. doi:10.1111/j.1469-8137.2004.01015.x

Huang, B., 2006. Plant-Environment Interactions, Third Edition. CRC Press. doi:10.1201/9781420019346 
ICRISAT, -, 2009. Fertilizer Microdosing: Boosting Production in unproductive lands.

Kano-Nakata, M., Gowda, V.R.P., Henry, A., Serraj, R., Inukai, Y., Fujita, D., Kobayashi, N., Suralta, R.R., Yamauchi, A., 2013. Functional roles of the plasticity of root system development in biomass production and water uptake under rainfed lowland conditions. F. Crop. Res. 144, 288-296. doi:10.1016/J.FCR.2013.01.024

Kano, M., Inukai, Y., Kitano, H., Yamauchi, A., 2011. Root plasticity as the key root trait for adaptation to various intensities of drought stress in rice. Plant Soil 342, 117-128. doi:10.1007/s11104-010-0675-9

Kapoor, V., Singh, U., Patil, S.K., Magre, H., Shrivastava, L.K., Mishra, V.N., Das, R.O., Samadhiya, V.K., Sanabria, J., Diamond, R., 2008. Rice Growth, Grain Yield, and Floodwater Nutrient Dynamics as Affected by Nutrient Placement Method and Rate. Agron. J. 100, 526. doi:10.2134/agronj2007.0007

Kato, Y., Abe, J., Kamoshita, A., Yamagishi, J., 2006. Genotypic Variation in Root Growth Angle in Rice (Oryza sativa L.) and its Association with Deep Root Development in Upland Fields with Different Water Regimes. Plant Soil 287, 117-129. doi:10.1007/s11104-006-9008-4

Kato, Y., Tajima, R., Homma, K., Toriumi, A., Yamagishi, J., Shiraiwa, T., Mekwatanakarn, P., Jongdee, B., 2013. Root growth response of rainfed lowland rice to aerobic conditions in northeastern Thailand. Plant Soil 368, 557567. doi:10.1007/s11104-012-1538-3

Kato, Y., Tajima, R., Toriumi, A., Homma, K., Moritsuka, N., Shiraiwa, T., Yamagishi, J., Mekwatanakern, P., Chamarerk, V., Jongdee, B., 2016. Grain yield and phosphorus uptake of rainfed lowland rice under unsubmerged soil stress. F. Crop. Res. 190, 54-59. doi:10.1016/J.FCR.2016.01.004

Kirk, G.J.D., George, T., Courtois, B., Senadhira, D., 1998. Opportunities to improve phosphorus efficiency and soil fertility in rainfed lowland and upland rice ecosystems. F. Crop. Res. 56, 73-92. doi:10.1016/S03784290(97)00141-X

Kirk, G.J.D., Yu, T.R., Choudhury, F.A., 1990. Phosphorus chemistry in relation to water regime. Phosphorus Requir. Sustain. Agric. Asia Ocean. Proc. a Symp. 6-10 March 1989. 211-223.

Kono, Y., Igeta, M., Yamada, N., 1972. Studies on the Developmental Physiology of the Lateral Roots in Rice Seminal Roots. Japanese J. Crop Sci. 41, 192-204. doi:10.1626/jcs.41.192

LaHue, G.T., Chaney, R.L., Adviento-Borbe, M.A., Linquist, B.A., 2016. Alternate wetting and drying in high yielding direct-seeded rice systems accomplishes multiple environmental and agronomic objectives. Agric. Ecosyst. Environ. 229, 30-39. doi:10.1016/J.AGEE.2016.05.020

Lilley, J.M., Fukai, S., 1994. Effect of timing and severity of water deficit on four diverse rice cultivars I. Rooting pattern and soil water extraction. F. Crop. Res. 37, 205-213. doi:10.1016/0378-4290(94)90099-X

Malhi, S.S., Zentner, R.P., Heier, K., 2001. Banding increases effectiveness of fertilizer P for alfalfa production. Nutr. Cycl. Agroecosystems 59, 1-11. doi:10.1023/A:1009889218829

Margenot, A.J., Singh, B.R., Rao, I.M., Sommer, R., 2016. Phosphorus fertilization and management in soils of SubSaharan Africa, in: Lal, Rattan and Stewart, B.A. (Ed.), Soil Phosphorus . CRPC Press, p. p.151-208.

Matsuo, N., Mochizuki, T., 2009. Growth and Yield of Six Rice Cultivars under Three Water-saving Cultivations. Plant Prod. Sci. 12, 514-525. doi:10.1626/pps.12.514

Nestler, J., Keyes, S.D., Wissuwa, M., 2016. Root hair formation in rice ( Oryza sativa L.) differs between root types and is altered in artificial growth conditions. J. Exp. Bot. 67, 3699-3708. doi:10.1093/jxb/erw115

Nhamo, N., Rodenburg, J., Zenna, N., Makombe, G., Luzi-Kihupi, A., 2014. Narrowing the rice yield gap in East and Southern Africa: Using and adapting existing technologies. Agric. Syst. 131, 45-55.

doi:10.1016/J.AGSY.2014.08.003 
Nkebiwe, P.M., Weinmann, M., Bar-Tal, A., Müller, T., 2016. Fertilizer placement to improve crop nutrient acquisition and yield: A review and meta-analysis. F. Crop. Res. 196, 389-401. doi:10.1016/j.fcr.2016.07.018

729

730

731

732

733

734

735

736

737

738

739

740

741

742

743

744

745

746

747

748

749

750

751

752

753

754

755

756

757

758

759

760

761

762

763

764

765

766

767

768

769

Nziguheba, G., Zingore, S., Kihara, J., Merckx, R., Njoroge, S., Otinga, A., Vandamme, E., Vanlauwe, B., 2016. Phosphorus in smallholder farming systems of sub-Saharan Africa: implications for agricultural intensification. Nutr. Cycl. Agroecosystems 104, 321-340. doi:10.1007/s10705-015-9729-y

Okada, K., Kondo, M., Ando, H., Kakuda, K., 2002. Water uptake under water stress at panicle initiation stage in upland rice as affected by previous soil water regimes. Soil Sci. Plant Nutr. 48, 151-158. doi:10.1080/00380768.2002.10409185

Price, A.H., Cairns, J.E., Horton, P., Jones, H.G., Griffiths, H., 2002. Linking drought-resistance mechanisms to drought avoidance in upland rice using a QTL approach: progress and new opportunities to integrate stomatal and mesophyll responses. J. Exp. Bot. 53, 989-1004. doi:10.1093/jexbot/53.371.989

Raboin, L.-M., Randriambololona, T., Radanielina, T., Ramanantsoanirina, A., Ahmadi, N., Dusserre, J., 2014. Upland rice varieties for smallholder farming in the cold conditions in Madagascar's tropical highlands. F. Crop. Res. 169, 11-20. doi:10.1016/J.FCR.2014.09.006

Ramasamy, S., ten Berge, H.F.M., Purushothaman, S., 1997. Yield formation in rice in response to drainage and nitrogen application. F. Crop. Res. 51, 65-82. doi:10.1016/S0378-4290(96)01039-8

Sahrawat, K.L., 2005. Iron Toxicity in Wetland Rice and the Role of Other Nutrients. J. Plant Nutr. 27, 1471-1504. doi:10.1081/PLN-200025869

Saito, K., Dieng, I., Toure, A.A., Somado, E.A., Wopereis, M.C.S., 2015. Rice yield growth analysis for 24 African countries over 1960-2012. Glob. Food Sec. 5, 62-69. doi:10.1016/j.gfs.2014.10.006

Saito, K., Nelson, A., Zwart, S.J., Niang, A., Sow, A., Yoshida, H., Wopereis, M.C.S., 2013. Towards a better understanding of biophysical determinants of yield gaps and the potential for expansion of the rice area in Africa., in: Realizing Africa's Rice Promise. CABI, Wallingford, pp. 188-203. doi:10.1079/9781845938123.0188

Sánchez, P.A., 2019. Properties and management of soils in the tropics, Second. ed. Cambridge University Press, Cambridge.

Sandhu, N., Subedi, S.R., Yadaw, R.B., Chaudhary, B., Prasai, H., Iftekharuddaula, K., Thanak, T., Thun, V., Battan, K.R., Ram, M., Venkateshwarlu, C., Lopena, V., Pablico, P., Maturan, P.C., Cruz, M.T.S., Raman, K.A., Collard, B., Kumar, A., 2017. Root Traits Enhancing Rice Grain Yield under Alternate Wetting and Drying Condition. Front. Plant Sci. 8, 1879. doi:10.3389/fpls.2017.01879

Schachtman, D.P., Reid, R.J., Ayling, S., 1998. Phosphorus Uptake by Plants: From Soil to Cell. Plant Physiol. 116, 447-53.

Seng, V., Bell, R.W., Willett, I.R., Nesbitt, $<<1>$ H.J., 1998. Phosphorus nutrition of rice in relation to flooding and temporary loss of soil-water saturation in two lowland soils of Cambodia. Plant Soil 207, 121-132. doi:10.1023/A:1026452029146

Shaibu, Y.A., Mloza Banda, H.R., Makwiza, C.N., Malunga, J.C., 2015. Grain yield performance of upland and lowland rice varieties under water saving irrigation through alternate wetting and drying in sandy clay loams of southern Malawi. Exp. Agric. 51, 313-326. doi:10.1017/S0014479714000325

Smolders, E., Baetens, E., Verbeeck, M., Nawara, S., Diels, J., Verdievel, M., Peeters, B., De Cooman, W., Baken, S., 2017. Internal Loading and Redox CycSmolders E, Baetens E, Verbeeck M, et al. 2017. Internal Loading and Redox Cycling of Sediment Iron Explain Reactive Phosphorus Concentrations in Lowland Rivers. Environmental Science \& Technology 51: 2584-2592.ling of Sedime. Environ. Sci. Technol. 51, 2584-2592. doi:10.1021/acs.est.6b04337

van der Eijk, D., 2006. Initial and residual effects of fertilizer phosphorus on soil phosphorus and maize yields on 
phosphorus fixing soils: A case study in south-west Kenya. Agric. Ecosyst. Environ. 116, 104-120.

772

773

774

775

776

777

778

779

780

781

782

783

784

785

786

787

788

789

790

791

792

793

794

795

796

797

798

799

800

801

802

803

804

805

806

van Oort, P.A.J., Saito, K., Tanaka, A., Amovin-Assagba, E., Van Bussel, L.G.J., van Wart, J., de Groot, H., van Ittersum, M.K., Cassman, K.G., Wopereis, M.C.S., 2015. Assessment of rice self-sufficiency in 2025 in eight African countries. Glob. Food Sec. 5, 39-49. doi:10.1016/J.GFS.2015.01.002

Vandamme, E., Ahouanton, K., Mwakasege, L., Mujuni, S., Mujawamariya, G., Kamanda, J., Senthilkumar, K., Saito, K., 2018. Phosphorus micro-dosing as an entry point to sustainable intensification of rice systems in subSaharan Africa. F. Crop. Res. 222, 39-49. doi:10.1016/j.fcr.2018.02.016

Wade, L.J., George, T., Ladha, J.K., Singh, U., Bhuiyan, S.I., Pandey, S., 1998. Opportunities to manipulate nutrientby-water interactions in rainfed lowland rice systems. F. Crop. Res. 56, 93-112. doi:10.1016/\$03784290(97)00142-1

Wade, L.J., McLaren, C.G., Quintana, L., Harnpichitvitaya, D., Rajatasereekul, S., Sarawgi, A.K., Kumar, A., Ahmed, H.U., Sarwoto, Singh, A.K., Rodriguez, R., Siopongco, J., Sarkarung, S., 1999. Genotype by environment interactions across diverse rainfed lowland rice environments. F. Crop. Res. 64, 35-50. doi:10.1016/\$03784290(99)00049-0

Yamauchi, A., Kono, Y., Tatsumi, J., 1987. Comparison of root system structures of 13 species of cereals. Japanese J. Crop Sci. 56, 618-631. doi:10.1626/jcs.56.618

Yang, J., Liu, K., Wang, Z., Du, Y., Zhang, J., 2007. Water-Saving and High-Yielding Irrigation for Lowland Rice by Controlling Limiting Values of Soil Water Potential. J. Integr. Plant Biol. 49, 1445-1454. doi:10.1111/j.16729072.2007.00555.x

Yang, J., Zhang, H., Zhang, J., 2012. Root Morphology and Physiology in Relation to the Yield Formation of Rice. J. Integr. Agric. 11, 920-926. doi:10.1016/S2095-3119(12)60082-3

Yoshida, S., 1981. Fundamentals of rice crop science. Fundam. rice Crop Sci.

Zapata, F., Roy, R.N., Food and Agriculture Organization of the United Nations. Land and Water Development Division., International Atomic Energy Agency., 2004. Use of phosphate rocks for sustainable agriculture. Food and Agriculture Organization of the United Nations.

Zenna, N., Senthilkumar, K., Sie, M., 2017. Rice Production in Africa, in: Rice Production Worldwide. Springer International Publishing, Cham, pp. 117-135. doi:10.1007/978-3-319-47516-5_5

Zhan, A., Chen, X., Li, S., 2014. The combination of localized phosphorus and water supply indicates a high potential for savings of irrigation water and phosphorus fertilizer. J. Plant Nutr. Soil Sci. 177, 884-891. doi:10.1002/jpln.201400011

Zhan, A., Schneider, H., Lynch, J.P., 2015. Reduced Lateral Root Branching Density Improves Drought Tolerance in Maize. Plant Physiol. 168, 1603-15. doi:10.1104/pp.15.00187

Zhang, H., Xue, Y., Wang, Z., Yang, J., Zhang, J., 2009. An Alternate Wetting and Moderate Soil Drying Regime Improves Root and Shoot Growth in Rice. Crop Sci. 49, 2246. doi:10.2135/cropsci2009.02.0099

Zhao, D.L., Bastiaans, L., Atlin, G.N., Spiertz, J.H.J., 2007. Interaction of genotype $\times$ management on vegetative growth and weed suppression of aerobic rice. F. Crop. Res. 100, 327-340. doi:10.1016/J.FCR.2006.08.007 
